\title{
Article \\ Origin of the El Dragón Selenium Mineralization, Quijarro Province, Potosí, Bolivia
}

\author{
Günter Grundmann ${ }^{1}$ and Hans-Jürgen Förster ${ }^{2, *}$ \\ 1 Eschenweg 6, DE-32760 Detmold, Germany; grundmann.g@gmx.de \\ 2 Helmholtz Centre Potsdam German Research Centre for Geosciences GFZ, DE-14473 Potsdam, Germany \\ * Correspondence: forhj@gfz-potsdam.de; Tel.: +49-0331-288-28843
}

Academic Editor: Paul Sylvester

Received: 26 January 2017; Accepted: 26 April 2017; Published: 29 April 2017

\begin{abstract}
A re-examination of the El Dragón vein-type Se deposit using polarized light microscopy and scanning-electron microscopy combined with electron-microprobe analyses revealed the following results: the detection of (a) petrríčekite, krut'aite and penroseite close to endmember composition; (b) a yet unknown mineral of the ideal composition $\mathrm{CuNi}_{2} \mathrm{Se}_{4}$; (c) intermediate members of the vaesite-pyrite solid-solution series; and (d) a mineral with a composition intermediate between athabascaite and its yet unknown S-equivalent, $\mathrm{Cu}_{4} \mathrm{~S}_{5}$. Triggered by volcanic-hydrothermal activities around the Porco caldera, formation of the mineralization involved five episodes of fault formation and re-opening, fluid-mediated metal mobilization, metalliferous fluid infiltration, and mineral precipitation, re-deposition, and alteration that probably extended from $12 \mathrm{Ma}$ until today. The origin of the Se-vein was accomplished by the multiple injection of highly oxidized, metal-rich fluids into a fault at the interface between black shale and siltstone. These low-T solutions (estimated max. temperature $100{ }^{\circ} \mathrm{C}$, max. pressure 1 bar) possessed high to exceptionally Se fugacities $\left(\log f_{\text {Se2 }}\right.$ fluctuating between of -14.5 and -11.2 ) that prevailed for most of the evolution of the deposit, only interrupted once, during the episode of deposition of sulfides of $\mathrm{Cu}$ and $\mathrm{Fe}$ and resulting partial alteration of the pre-existing selenides. Formation of end-member krut'aite and native selenium implies a minimum $\log f_{\mathrm{Se} 2}$ of -11.2 at the final stage of vein formation. The likely source of Se and the accompanying metals $(\mathrm{Cu}, \mathrm{Ag}, \mathrm{Ni}, \mathrm{Co}, \mathrm{Au}, \mathrm{Pb}, \mathrm{Hg}, \mathrm{Cd}, \mathrm{Fe}$ and $\mathrm{Bi})$ is the neighboring Kupferschiefer-type (possibly Devonian) black shale rich in framboidal pyrite, $\mathrm{Cu}$-sulfide aggregates, and organic matter. Deposition of Se-minerals occurred where the oxidized metal-bearing solutions became in contact with a reductant, associated with the reduction of mobile selenate to immobile selenide or elemental Se.
\end{abstract}

Keywords: origin; selenium mineralization; siltstone; black shale; unnamed $\mathrm{CuNi}_{2} \mathrm{Se}_{4}$; unnamed $\mathrm{Cu}_{4} \mathrm{~S}_{5}$; endmember krut'aite; endmember penroseite; vaesite; genetic sequence; El Dragón; Bolivia

\section{Introduction}

Research on selenium minerals conducted in the past few years focused on the search for new species, on the determination of their chemical composition, and on the definition of their crystal structure [1-10]. In contrast, comparatively little effort was spent on studying the origin of their host mineralization, including implications on the source of the selenium and accompanying elements (e.g., [11]). This conclusion also holds for the two selenium occurrences in the Andes of Bolivia: Virgen de Surumi (also known as "Pacajake") [12,13], district of Hiaco de Charcas, Chayanta Province, and El Dragón, Antonio Quijarro Province, both in the Department of Potosí [14]. Virgen de Surumi is the type locality of ahlfeldite $(\mathrm{Ni}, \mathrm{Co}) \mathrm{SeO}_{3} \cdot 2 \mathrm{H}_{2} \mathrm{O}$, mandarinoite $\mathrm{Fe}^{3+}{ }_{2}\left(\mathrm{SeO}_{3}\right) \cdot 4 \mathrm{H}_{2} \mathrm{O}$, olsacherite $\mathrm{Pb}_{2}\left(\mathrm{SeO}_{4}\right)\left(\mathrm{SO}_{4}\right)$, and penroseite $\mathrm{NiSe}_{2}$. El Dragón is the type locality of eldragónite $\mathrm{Cu}_{6} \mathrm{BiSe}_{4}\left(\mathrm{Se}_{2}\right)$ [2], grundmannite CuBiSe 2 [5], hansblockite $(\mathrm{Cu}, \mathrm{Hg})(\mathrm{Bi}, \mathrm{Pb}) \mathrm{Se}_{2}$ [6], quijarroite $\mathrm{Cu}_{6} \mathrm{HgPb}_{2} \mathrm{Bi}_{4} \mathrm{Se}_{12}$ [7], unnamed phase 
" $\mathrm{C}$ " [5], and the alteration minerals favreauite $\mathrm{PbBiCu}_{6} \mathrm{O}_{4}\left(\mathrm{SeO}_{3}\right)_{4}(\mathrm{OH}) \cdot \mathrm{H}_{2} \mathrm{O}$ [3] and alfredopetrovite $\mathrm{Al}_{2}\left(\mathrm{Se}^{4+} \mathrm{O}_{3}\right)_{3} \cdot 6 \mathrm{H}_{2} \mathrm{O}[8]$.

Available genetic concepts on the origin of the low temperature hydrothermal vein-type selenium mineralization at El Dragón, which forms the subject of this paper, are distinct and consider only one stage of the ore-forming process. Paar et al. [2] attributed the precipitation of the $\mathrm{Cu}-\mathrm{Hg}-\mathrm{Bi}-\mathrm{Pb}-$ selenide assemblage to a late event of brittle deformation, causing brecciation of the pre-existing $\mathrm{Cu}-\mathrm{Co}-\mathrm{Ni}-\mathrm{Se}$ krut'aite-penroseite main mineralization and subsequent infiltration of another fluid phase containing $\mathrm{Bi}, \mathrm{Pb}$ and $\mathrm{Hg}$. Förster et al. [5] supposed that Se and the accompanying elements were transported within the same fluid, with $\mathrm{Bi}-\mathrm{Hg}-\mathrm{Pb}$ becoming progressively enriched in the fluid after formation of the main selenium minerals. Our examination of 260 polished sections of the selenide vein and neighboring rocks permitted to develop an improved genetic model for El Dragón (cf. Section 2). In this paper, we report new microstructural and chemical data for the selenium vein mineralization, also addressing its host and country rocks. We provide a genetic model that considers the relationship between crystallization and deformation of primary and secondary minerals, and we discuss possible mechanisms for the origin and formation of that unique Se occurrence.

\section{Regional Geology}

The abandoned El Dragón mine (entrance and dump) is located at $\sim 19^{\circ} 49^{\prime} 23.90^{\prime \prime} \mathrm{S}$ (latitude), $65^{\circ} 55^{\prime} 00.60^{\prime \prime} \mathrm{W}$ (longitude), at an altitude of $4160 \mathrm{~m}$ above sea level, about $5 \mathrm{~km}$ east of the Porco mine, which is currently Bolivia's most productive zinc producer [15]. Main ore minerals of the Porco $\mathrm{Ag}-\mathrm{Pb}-\mathrm{Zn}-\mathrm{Sn}$ deposit are sphalerite, galena, cassiterite, and primary Ag minerals, such as pyrargyrite, acanthite, and stephanite. The fissure-filling vein mineralization is zoned around the 8.6 Ma Huayna Porco stock in the center of the Porco caldera, which formed $12 \mathrm{Ma}$ ago during the eruption of the dacitic Porco tuff [15] (Figure 1a). The Porco caldera measures $5 \mathrm{~km} \mathrm{~N}-\mathrm{S}$ by $3 \mathrm{~km}$ E-W and caused in response to the eruption of the dacitic Porco tuff a radially distributed system of faults and fractures in the surrounding Paleozoic and Mesozoic sediments. Neighboring host rocks are Ordovician phyllites overlain by lower Cretaceous sandstones, deformed into a series of north- to northwest-trending folds (Figure 1b). The sediments are partly covered by andesitic to dacitic lavas of the Los Frailes volcanic field that sealed off the former topography. Rock units east of the Porco caldera show strong fracturing with preferentially NW-SE- and SW-NE-trending directions.

During the Andean orogeny, the Andes Mountains experienced compressional followed by an intense extensional tectonism [16]; the sedimentary cover was decomposed by thrust faults and normal faults. Convective fluid flow was triggered locally around volcanic pipes and shallow magma chambers. The faults and fractures acted as geochemical traps, with the present ground surface closely resembling the surface that existed at the presumed time of mineralization. The El Dragón mine is located left of the Rio Jaya Mayu, cutting through a series of thin-stratified, pyrite-rich black shales and reddish-grey, hematite-bearing siltstones of probably Devonian age, dipping $40^{\circ}$ to the north (Figure 1c). Water springs are especially defined to outcropping black shales. The almost vertical, substantially smooth-walled selenide vein filling has an average thickness of $2 \mathrm{~cm}$, with rare buckling of up to $6 \mathrm{~cm}$ and thinning to the mm-range. The areal extent of the selenium vein mineralization was estimated $12 \mathrm{~m}$ long and $2 \mathrm{~m}$ high. It is located in the center of a 1.5-m-wide shear zone (average trend $135^{\circ}$ ), from which a total of roughly 100 kilogram of high-grade Se-ore was mined between 1970 and 1987. Its country-rock black shale unit forms a sequence of up to $120 \mathrm{~m}$ thickness. It contains a boudinage of thin lenses and layers of siltstone up to $5 \mathrm{~m}$ thick (represented by sample 5247), which are parallel to sedimentary bedding. The selenium squat extended exclusively within the siltstone bedding and, actually, represents the filling of open spaces between siltstone boudins. An adit approximately $15 \mathrm{~m}$ long has been driven into that north dipping siltstone host rock. The gallery roof ended in barren black shale (cf. Figure 1c, and Figure 7 in [14]). A recently discovery thin krutàite-bearing veinlet at the interface between a black shale and a siltstone some $100 \mathrm{~m}$ away from the El Dragón mine is mineralogically and microstructurally quasi-identical to the selenium vein described here. 


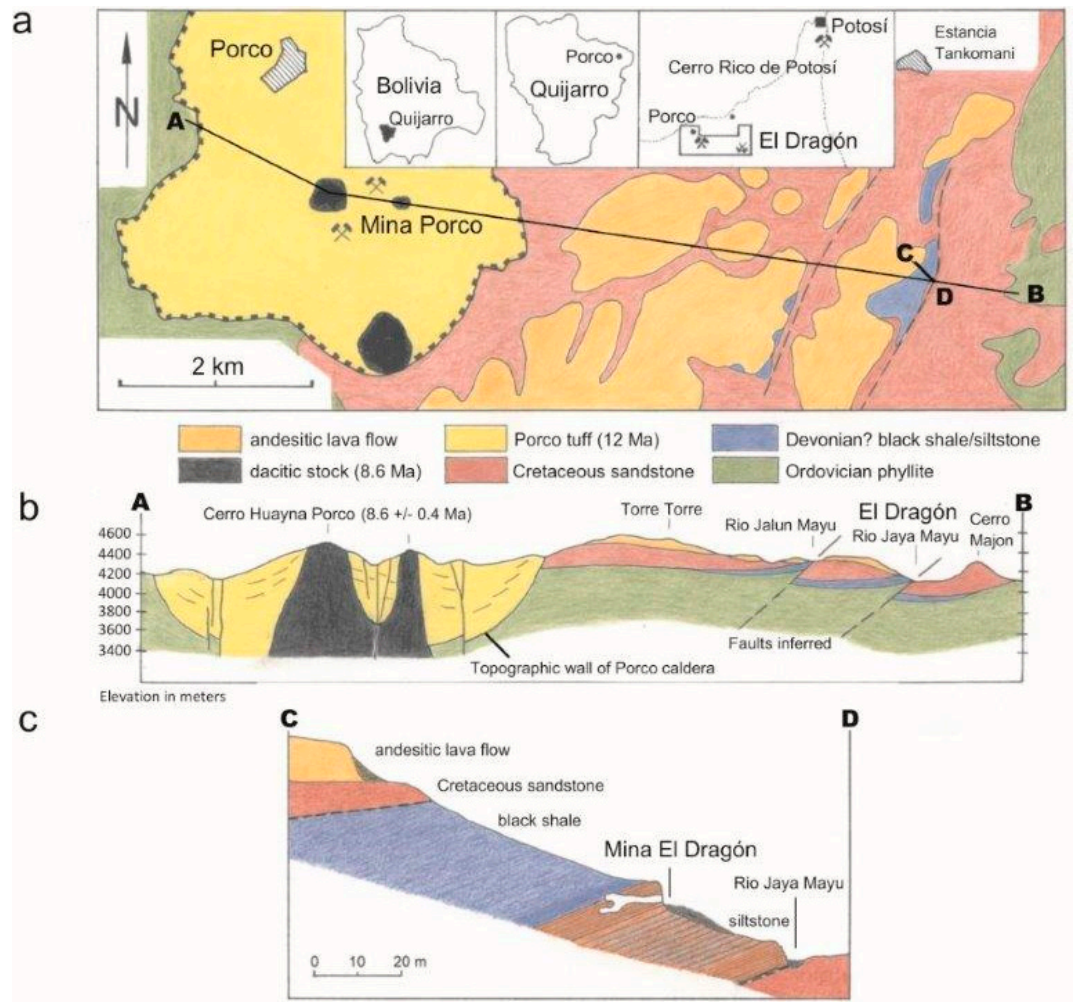

Figure 1. (a) Simplified geological sketch map of the Porco mining area and the region east of it, with the location of the cross sections A-B and C-D shown below; (b) Cross section through the Porco area; and (c) idealized cross section showing the El Dragon Se-vein and its host (siltstone) and country rocks (black shale).

\section{Methods and Results}

Establishing the relationship of host and country-rock deformation with the selenium-vein formation, the petrographic and microstructural observations mainly obtained by optical microscopy (Leitz/Leica DMRM polarizing microscope, Type 301-371-010, Leitz/Leica, Wetzlar, Germany) will be provided in the following order: (1) siltstone (Se-vein host rock); (2) selenium vein; and (3) black shale (Se-vein country rock). Mineral compositions were determined for selenides and sulfides from the Se-vein and sulfides from the black shale, using an automated field-emission JEOL 8500F (JEOL, Akishima, Japan) electron microprobe operated in wavelength-dispersion method. All minerals were routinely checked for concentrations of $\mathrm{Cu}, \mathrm{Ag}, \mathrm{Pb}, \mathrm{Hg}, \mathrm{Fe}, \mathrm{Co}, \mathrm{Ni}, \mathrm{As}, \mathrm{Sb}, \mathrm{Bi}, \mathrm{S}$ and $\mathrm{Se}$. The analytical conditions are reported in [5-7].

\subsection{Petrography of Siltstone}

Hand specimens of siltstone are reddish brown (Figure 2a). Grain size ranges between 0.007 and $0.02 \mathrm{~mm}$, classifying it as coarse silt. Plane lamination is spotty stained with flaky white mica. Graded bedding and cross bedding alternated in the millimeter range (Figure 2b). Compression tectonics caused finely divided foliation in the form of boudinage parallel and transverse to stratification. Areas of strongest foliation are brownish stained by goethite (Figure $2 b$ ). Optical thin-section analysis (Figure 2c,d) revealed the following modal mineralogy (estimated volume percentages in parentheses): quartz $(60 \%)$, feldspar $(2 \%)$, white mica $(2 \%)$, and skeletal opal $(2 \%)$; minor accessory components $(<1 \%)$ involve chalcedony, sponge spicule fragments (Figure 2e), amphibole, tourmaline, apatite, rutile, titanite, zircon, pyrite, chalcopyrite, and graphite. Matrix cement consists of clay $(20 \%)$, hematite $(10 \%)$, and goethite ( $2 \%$ ). Grain size of the finest-textured hematite cement averages to $2 \mu \mathrm{m}$ (Figure $2 \mathrm{f}$ ), thus providing an enormous surface area for redox-mediated processes. 

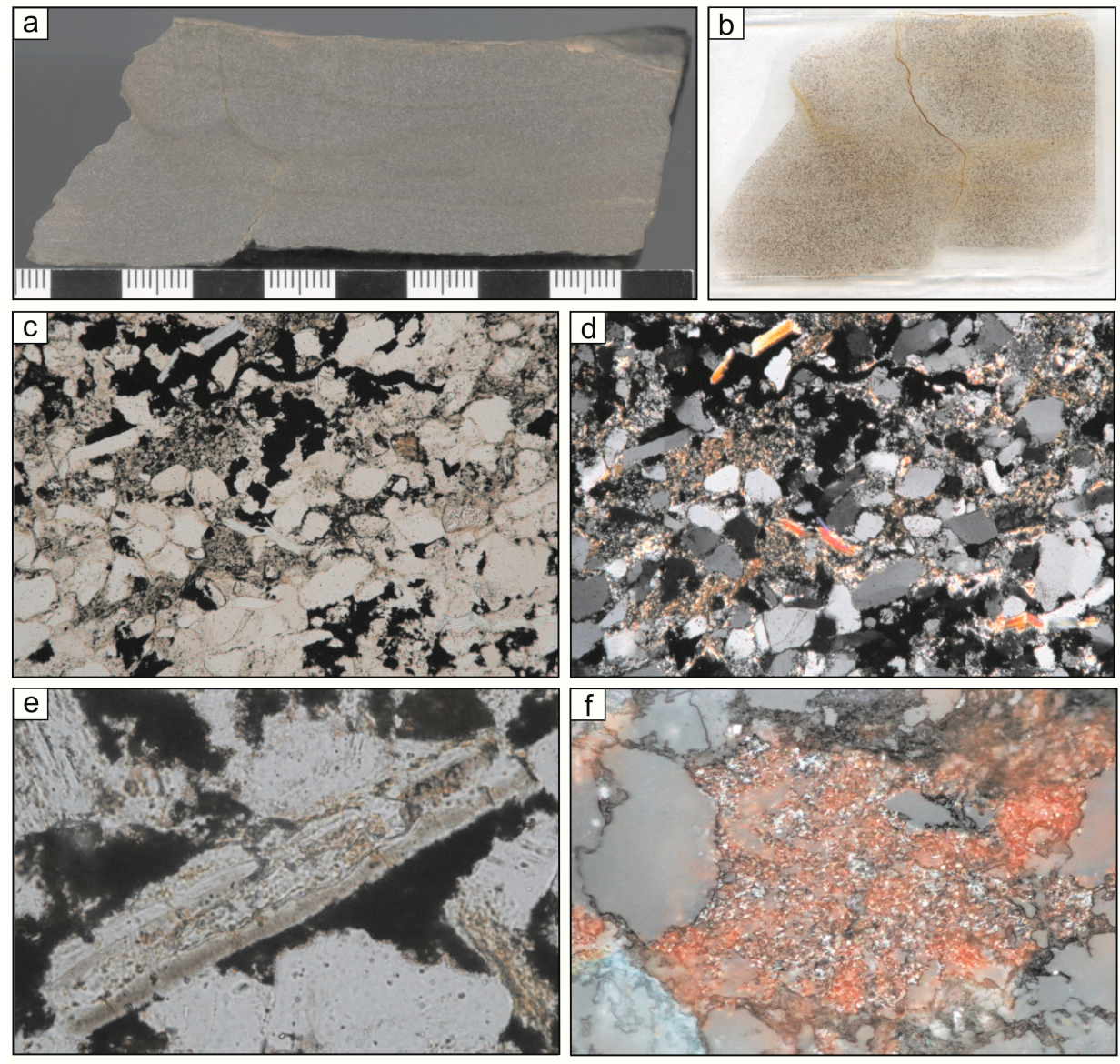

Figure 2. (a) Representative hand specimen of siltstone, oriented perpendicular to the sedimentary bedding (from above the gallery entrance of the El Dragón mine). Shortened boudinage bodies are outlined by a network of curved Fe-hydroxide fillings (scale bar in $\mathrm{cm}$ ); (b) Thin section of the left part of the specimen shown in (a); The dark brown staining is caused by thin Fe-hydroxide fillings; (c) Detailed view of (b) showing fine-grained quartz fragments embedded in an argillaceous matrix (grey) patchily enriched in fine-grained hematite aggregates (black opaque). Width $1 \mathrm{~mm}$; (d) Same as (c), but with crossed polarizers. Quartz grains generally show undulatory extinction and/or sub-grain boundaries; (e) Fragment of a completely silicified sponge spicule embedded in a matrix of fine-grained hematite, white mica and clay. Thin section, transmitted light. Width $200 \mu \mathrm{m}$; (f) Detailed view of the hematite-rich argillaceous matrix. Thin section, dispersed light dark-field image, width $100 \mu \mathrm{m}$.

\subsection{The El Dragón Se-Vein}

\subsubsection{Mineralogy and Structural Features}

The selenium mineralization represents a strongly brecciated, cavernous fault filling that cuts siltstones and black shales. Main minerals are members of the krut'aite-penroseite solid-solution series ( $~ 95$ vol \%); the remaining $\sim 5$ vol \% comprise other selenides, sulfides, and secondary alteration products. In addition to the "type minerals" reported in the Introduction Section, the primary mineralization includes native gold, clausthalite $\mathrm{PbSe}$, eskebornite $\mathrm{CuFeSe}_{2}$, klockmannite CuSe, petrovicite $\mathrm{Cu}_{3} \mathrm{HgPbBiSe}_{5}$, tiemannite $\mathrm{HgSe}$, umangite $\mathrm{Cu}_{3} \mathrm{Se}_{2}$, and watkinsonite $\mathrm{Cu}_{2} \mathrm{PbBi}_{4} \mathrm{Se}_{8}$. Late-stage primary and secondary minerals and subsequent alteration products include, among others, athabascaite $\mathrm{Cu}_{5} \mathrm{Se}_{4}$, penroseite, trogtalite $(\mathrm{Co}, \mathrm{Ni}, \mathrm{Cu}) \mathrm{Se}_{2}$, the unnamed Se-analog of fletcherite $\mathrm{CuNi}_{2} \mathrm{Se}_{4}$, chalcopyrite $\mathrm{CuFeS}_{2}$, pyrite $\mathrm{FeS}_{2}$, marcasite $\mathrm{FeS}_{2}$, intermediate members of the vaesite-pyrite solid-solution series $\mathrm{NiS}_{2}-\mathrm{FeS}_{2}$, covellite $\mathrm{CuS}$, petř́čekite CuSe $\mathrm{C}_{2}$, krut'aite CuSe 2 , ahlfeldite, allophane $\left(\mathrm{Al}_{2} \mathrm{O}_{3}\right)\left(\mathrm{SiO}_{2}\right)_{1.3-2} \cdot 2.5-3 \mathrm{H}_{2} \mathrm{O}$, felsőbányaite $\mathrm{Al}_{4}\left(\mathrm{SO}_{4}\right)(\mathrm{OH})_{10} \cdot 4 \mathrm{H}_{2} \mathrm{O}$, 
goethite $\alpha-\mathrm{Fe}^{3+} \mathrm{O}(\mathrm{OH})$, mandarinoite, lepidocrocite $\gamma-\mathrm{Fe}^{3+} \mathrm{O}(\mathrm{OH})$, linarite $\mathrm{PbCu}\left(\mathrm{SO}_{4}\right)(\mathrm{OH})_{2}$, malachite $\mathrm{Cu}_{2}\left(\mathrm{CO}_{3}\right)(\mathrm{OH})_{2}$, molybdomenite $\mathrm{PbSeO}_{3}$, schmiederite $\mathrm{Pb}_{2} \mathrm{Cu}_{2}\left(\mathrm{Se}^{6+} \mathrm{O}_{4}\right)\left(\mathrm{Se}^{4+} \mathrm{O}_{3}\right)(\mathrm{OH})_{4}$, olsacherite, and native selenium.

The most common k-p s. mineralization typically forms cockscomb crustaceous banding grown from the vein wall inwards, representing several stages of selenide deposition (Figure 3a,b). The k-p s. aggregates are optically zoned and show distinctive changes in the abundance and internal fabric of included minerals from core-to-rim. Krut'aite-penroseite aggregates often cement together and/or corrode randomly oriented angular fragments of the hematite-bearing siltstone host rock, which collapsed into open space of the vein, forming a typical rubble breccia (Figure 3a). Selenide precipitation on the surface of ferrous siltstone fragments caused reduction halos (average thickness $2 \mathrm{~mm}$ ), associated with the bleaching of the finest hematite cement (average grain size $2 \mu \mathrm{m}$ ) and impregnation of opaque k-p s. Principle gangue minerals are dolomite and minor quartz and baryte. The dolomite is filling voids preferentially in the central part of the vein (Figure 3b). Rock fragments inside the vein breccia represent almost exclusively siltstone. Vein selvages often show distinct fault-slip striation. The entire selenium vein experienced strong overprinting, with Fe-hydroxides and allophane being the most common alteration products.
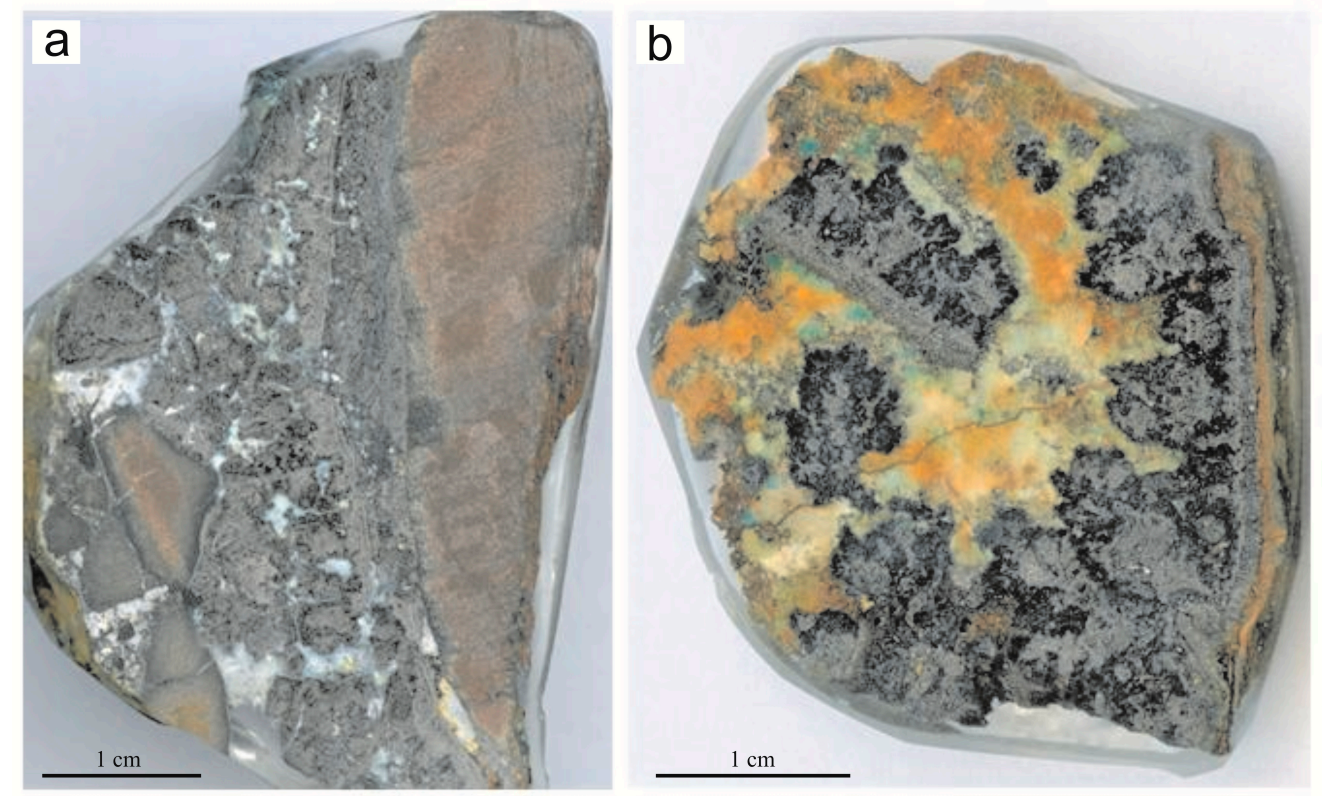

Figure 3. (a) Se-veinlet forming a typical rubble breccia, bordered to the right by the stratified siltstone host rock. Angular siltstone fragments exhibit zonal bleaching. Open spaces between the selenide fragments are filled by chalcomenite (blue) and allophane (white); (b) Another Se-veinlet with dolomite as principal gangue stained by goethite (orange) and chalcomenite (greenish blue). Mechanically undisturbed k-p s. mineralization typically displays a cockscomb crustaceous banding grown from the vein wall inwards (right). Note that large k-p s. fragments broke off from the vein wall and became cemented by the dolomite gangue in a tilted position.

\subsubsection{Micro-Structural Features and Genetic Sequence}

Figure 4 provides a summary of micro-textural evidence for the relationships between selenide growth and the sequence of deformation, precipitation and alteration. Figure 5 is a schematic sketch of a complex texture of selenides (colloform, crustaceous and zonal banding) in the order of sequence of their formation.

Four stages of selenide precipitation $(I)-(I V)$ and one stage of alteration $(V)$, triggered in each case by five brittle deformational events $(d 1)-(d 5)$, could be distinguished and are described below in its inferred age sequence (Figures 4 and 5): 
Deformation (d1): First vein opening and brecciation of the siltstone host rock.

Stage $I$ corresponds to colloform/poikilitic k-p s.-(g1) growth generation.

Deformation (d2): Second vein opening, fragmentation of stage $I$ selenides.

Stage II corresponds to k-p s.-(g2)-(g5) growth generations.

Deformation (d3): Third vein opening, fragmentation of stage I-II selenides.

Stage III corresponds to k-p s.-(g6) growth generation, forming fracture fillings.

Deformation (d4): Fourth vein opening, fragmentation of stage I-III selenides.

Stage $I V$ corresponds to krut'aite-(g7) growth generation, cementing pores and fractures.

Deformation (d5): Fifth vein opening, fragmentation of stage $\boldsymbol{I}-\boldsymbol{I V}$ selenides.

Stage $V$ corresponds to various alteration products forming growth generation (g8), cementing all previous structures.

Brittle deformation (d1) caused opening of an extension fracture zone and subsequent fluid flow into open spaces of the siltstone host rock, giving rise to stage $I$ selenide precipitation. The earliest generation of k-p s.-(g1), clausthalite-(g1) and watkinsonite-(g1) partly replaced fine-grained quartz, white mica and hematite along grain boundaries of the siltstone (Figure 6a,b). K-p s.-(g1) occurs either as colloform or poikilitic k-p s.-(g1)/goethite aggregates (1 mm maximum thickness) usually containing minute inclusions of newly grown tiemannite-(g1), clausthalite-(g1), eskebornite-(g1), watkinsonite-(g1), eldragónite-(g1), klockmannite-(g1), umangite-(g1), hematite-(g1), goethite-(g1), or native gold-(g1).

Subsequent cataclastic movement (d2) locally caused detachment and strong fragmentation of these earliest, thin selenide coatings, initiating main stage II selenide precipitation (Figure 7a). The colloform banded fabric of the k-p s.-(g1) has been partially co-folded and partially broken up in layers owing to their incompetent characteristics. Deposition of younger k-p s.-(g2) and clausthalite-(g2) occurred in the resultant cracks and voids (Figure $7 \mathrm{~b}$ ). Veinlets of umangite-(g2), klockmannite-(g2), clausthalite-(g2) and, subordinately, watkinsonite-(g2), eldragónite-(g2), tiemannite-(g2), eskebornite-(g2), and native gold-(g2) follow the grain boundaries and penetrate k-p s.-(g2), locally replacing it. This penetration is partly irregular and partly oriented on crystallographic planes of the k-p s.-(g2) (Figure 8a,b). The next growth generation k-p s.-(g3) formed an extremely fine-grained, usually highly porous network of skeletal, myrmecitic and/or streaked intergrowth of k-p s. and goethite, often surrounding earlier, isolated k-p s.-(g2) aggregates (Figure 9a,b). Sporadic minute inclusions of growth generation-(g3) are the same as in k-p s.-(g2). The branching of the very fine grained k-p s.-(g3) extended into un-oriented, pseudo-granular polygons of k-p s.-(g4), which show almost the same microstructural features as k-p s.-(g3). The k-p s.-(g4) aggregates host significant amounts of umangite-(g4), klockmannite-(g4), clausthalite-(g4), watkinsonite-(g4), eskebornite-(g4), eldragónite-(g4) and native gold-(g4). Shrinkage cracks in k-p s.-(g4), umangite-(g4), and klockmannite-(g4) filled with native gold-(g4) and/or other minerals give strong evidence that these selenides suffered significant loss of volume (Figure 10a,b).

K-p s.-(g4) became bordered by the oscillatory zoned growth generation k-p s.-(g5). These aggregates occur at the outermost parts of the colloform and crustaceous-banded selenides as euhedral to subhedral grains, which are often strongly zoned optically (Figure 11a,b). The color zoning of k-p s.-(g5) is striking and commonly systematic, with up to 10 more or less sharply separated zones distinguished by bluish to pinkish-cream hues. Inclusions of umangite-(g5), klockmannite-(g5), watkinsonite-(g5), eldragónite-(g5), eskebornite-(g5), and clausthalite-(g5) are largely confined to the bluish zones (Figure 11b). 


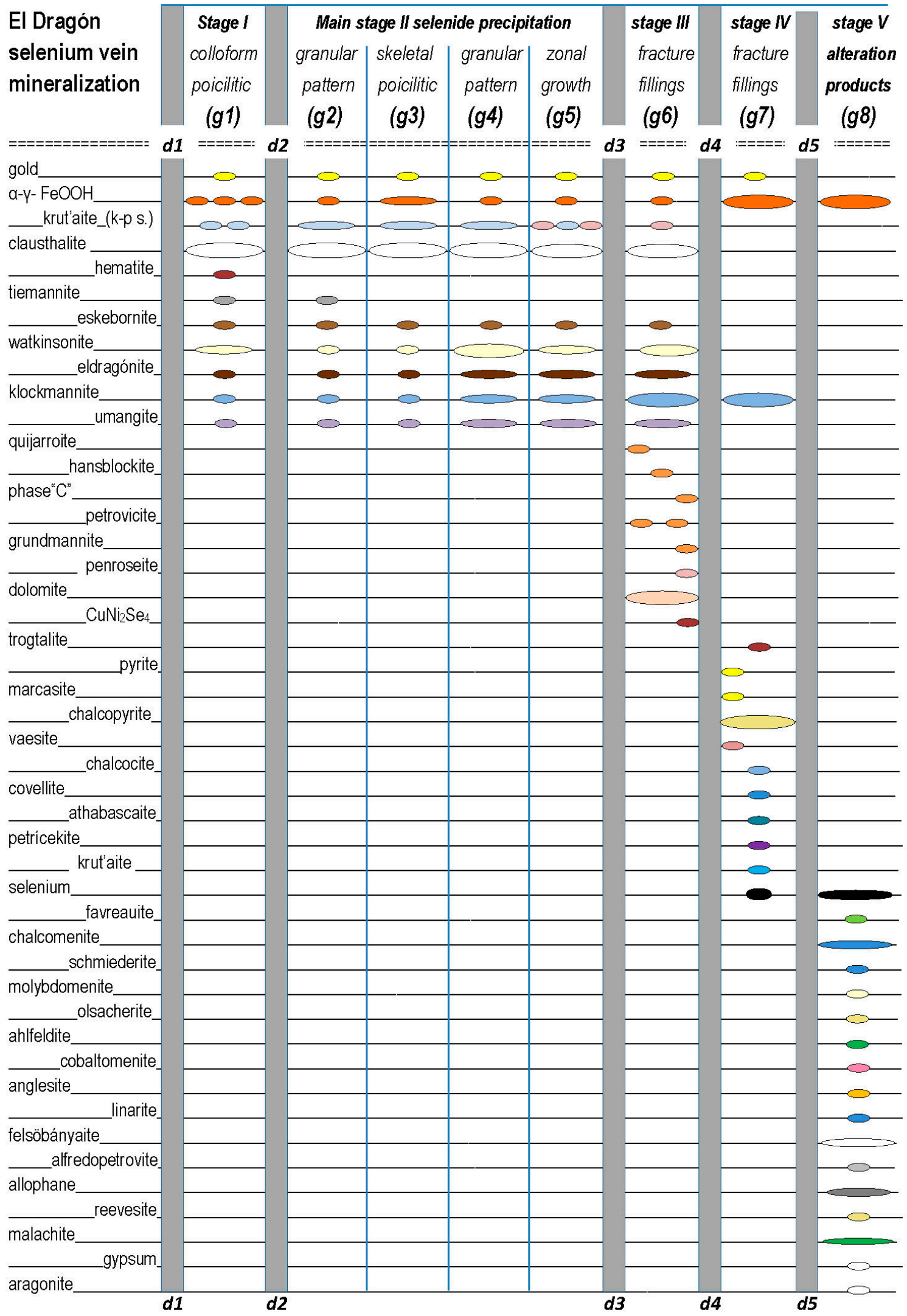

Figure 4. Paragenetic sequence and crystallization/deformation diagram for the El Dragón selenium mineralization. 


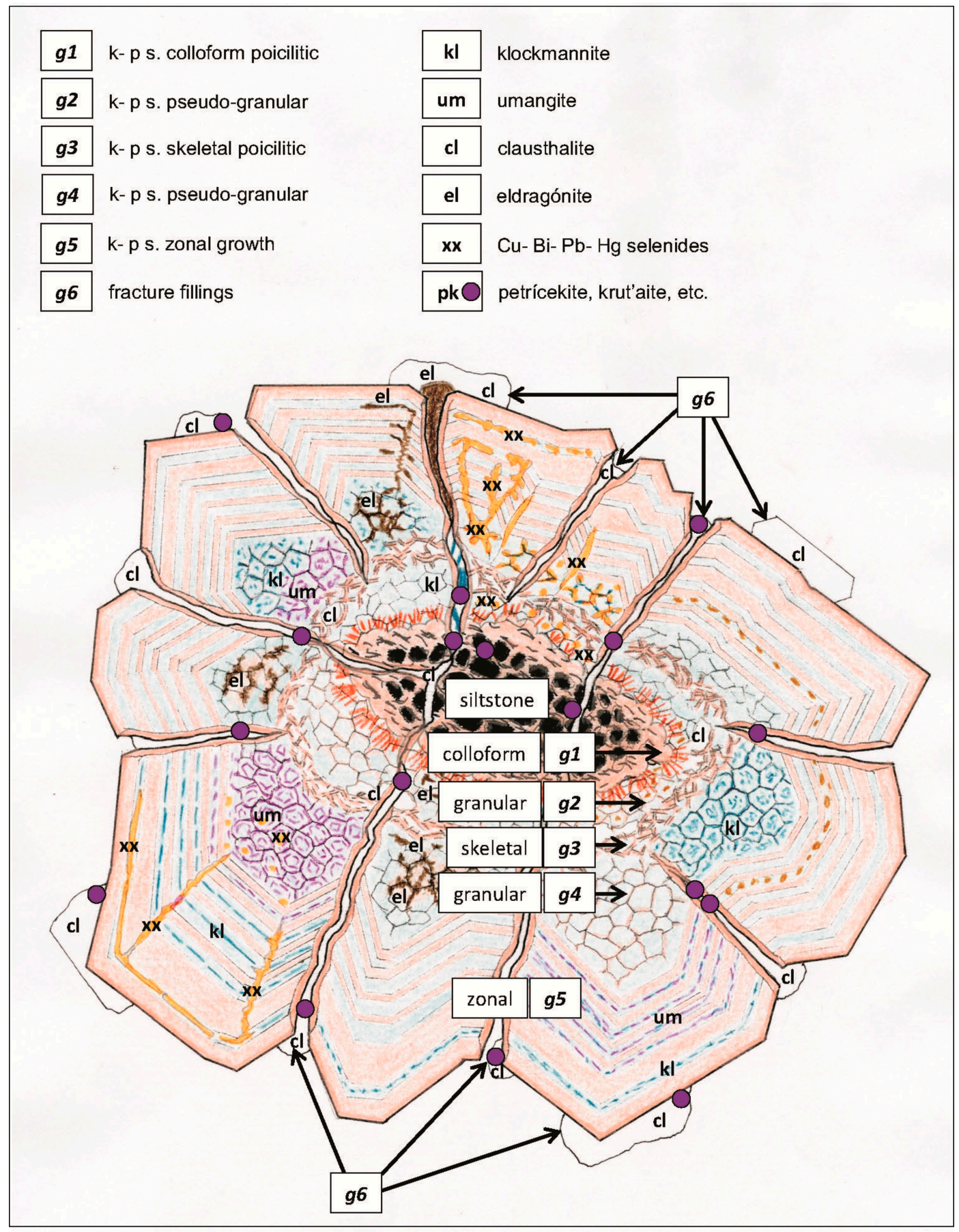

Figure 5. Schematic sketch of a tangential section $(\sim 1 \mathrm{~cm}$ in diameter) cutting through colloform and zonal banding of selenides that are surrounding a siltstone fragment (cf. Figure 4). See text for further explanations. 

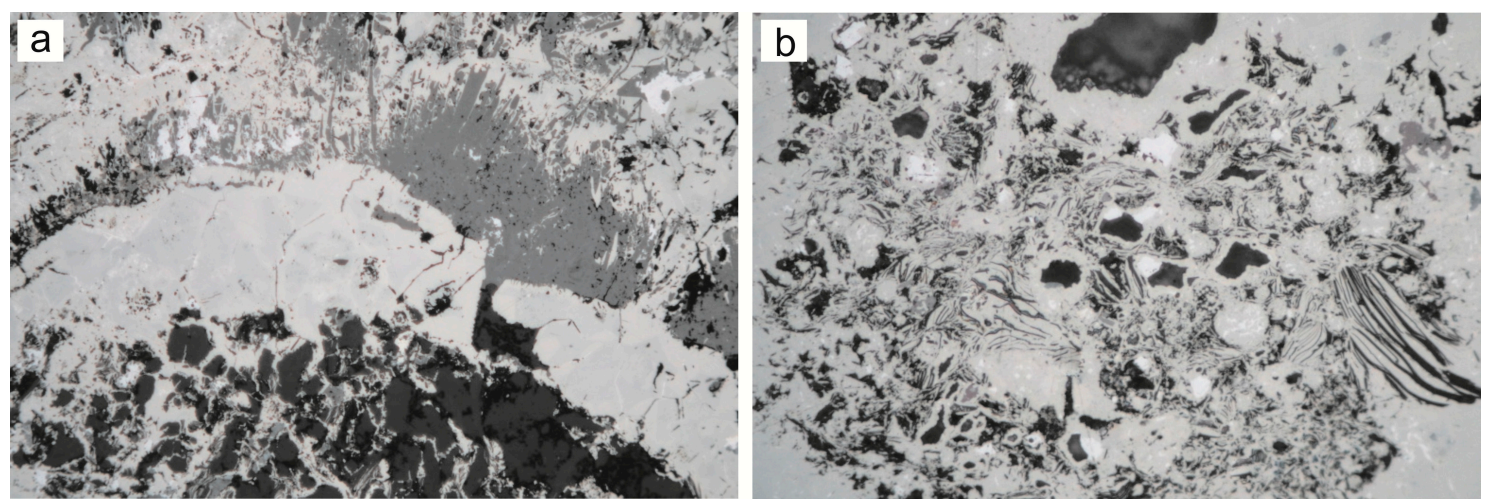

Figure 6. (a) Colloform k-p s.-(g1) partially replacing a siltstone fragment along the grain boundaries of quartz, white mica, and hematite. Clausthalite (bright) and fibrous goethite (grey) occur at the outer rim of spherulitic k-p s.-(g1). Width $500 \mu \mathrm{m}$, (b) Detailed view of a strongly corroded siltstone fragment. Width $200 \mu \mathrm{m}$.

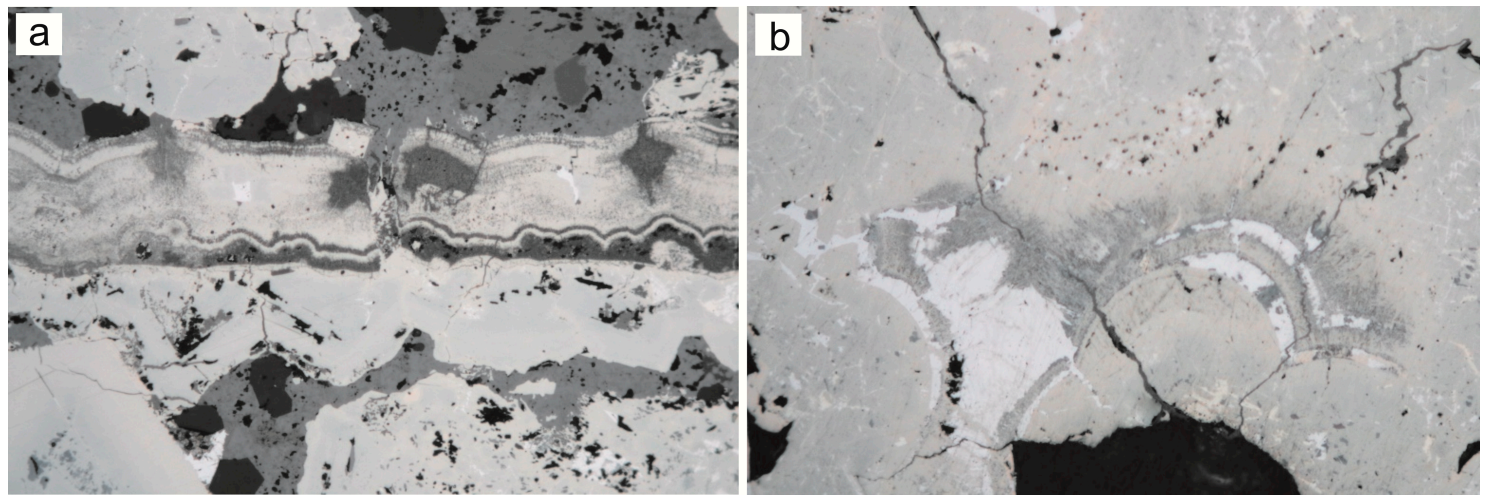

Figure 7. (a) Brittle deformation (d2) caused detachment and fragmentation of colloform-banded k-p s.-(g1). Resultant cracks and voids are filled by younger k-p s.-(g2) and clausthalite-(g2). Width $1 \mathrm{~mm}$, (b) Relic of colloform k-p s.-(g1), overgrown by k-p s.-(g2), partly broken up along the outer bands as result of their incompetent behavior, with the generated open spaces mainly filled by light-blue clausthalite-(g2). Width $500 \mu \mathrm{m}$.
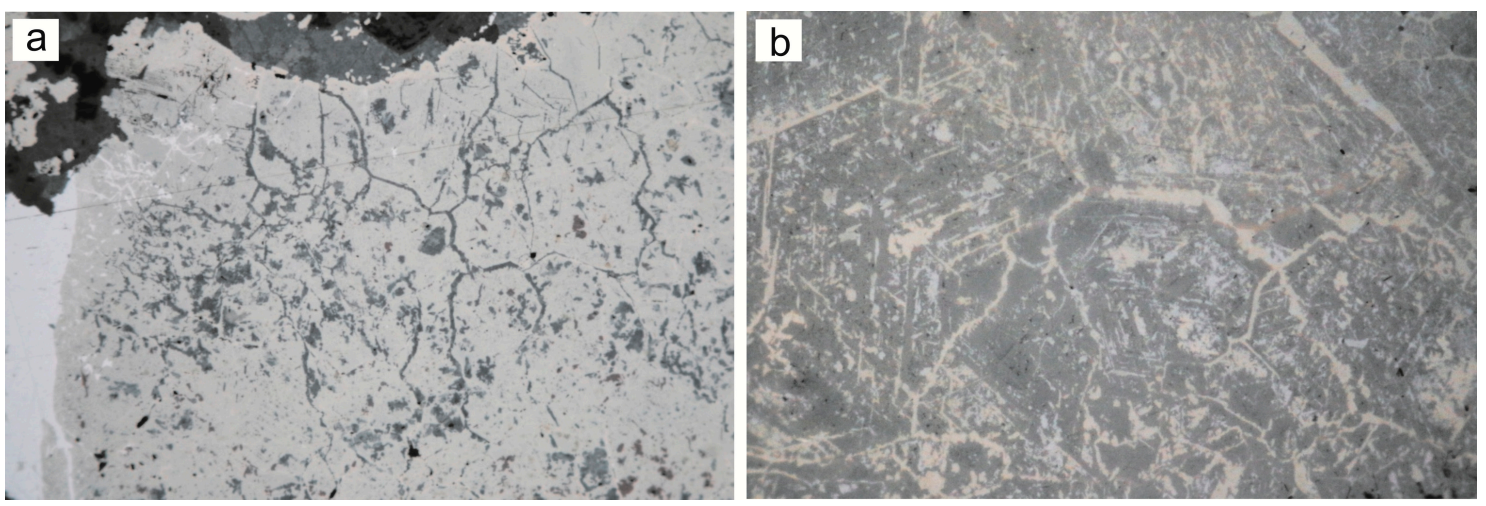

Figure 8. (a) Pseudo-granularly textured k-p s.-(g4) showing a network of smallest shrinkage cracks filled with younger selenides, in this case predominantly klockmannite (dark blue). Width $500 \mu \mathrm{m}$; (b) Pseudo-granular polygons of k-p s.-(g4) outlined by grains of watkinsonite (cream) and clausthalite (light blue) deposited along grain boundaries, which irregularly penetrate and replace k-p s.-(g1). Width $200 \mu \mathrm{m}$. 

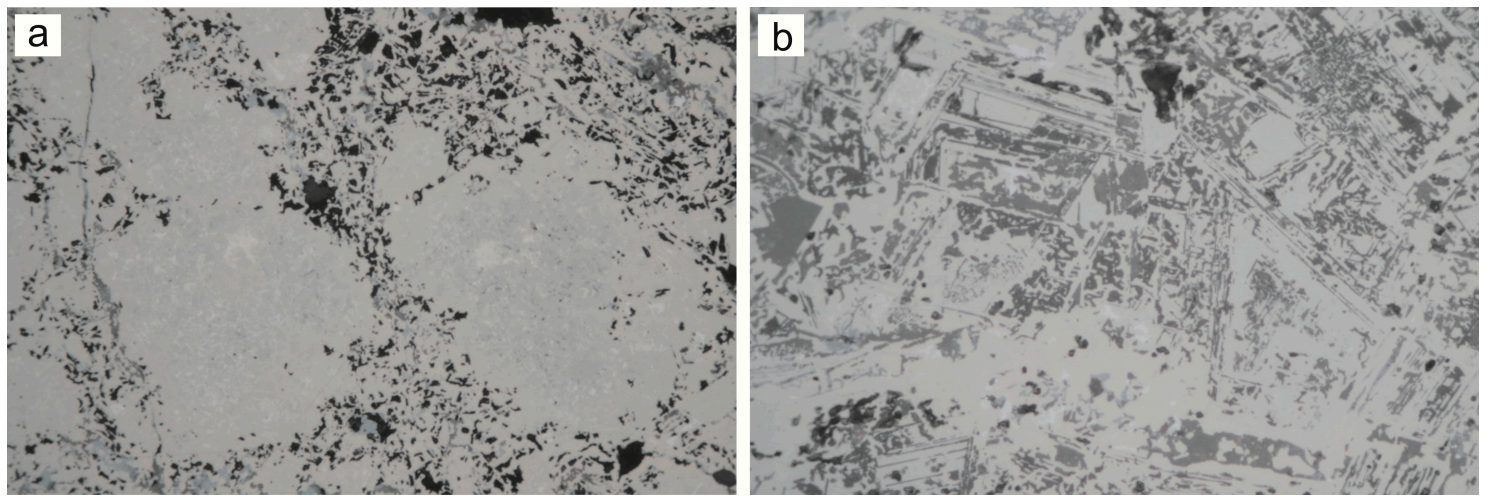

Figure 9. (a) k-p s.-(g3), forming a finest-grained, highly porous network of skeletal and myrmecitic aggregates, surrounding isolated k-p s.-(g2) rich in clausthalite and watkinsonite. Width $500 \mu \mathrm{m}$; (b) Closer view on k-p s.-(g3) shown in (a), illustrating its intensive intergrowth with goethite-(g3). Width $200 \mu \mathrm{m}$.
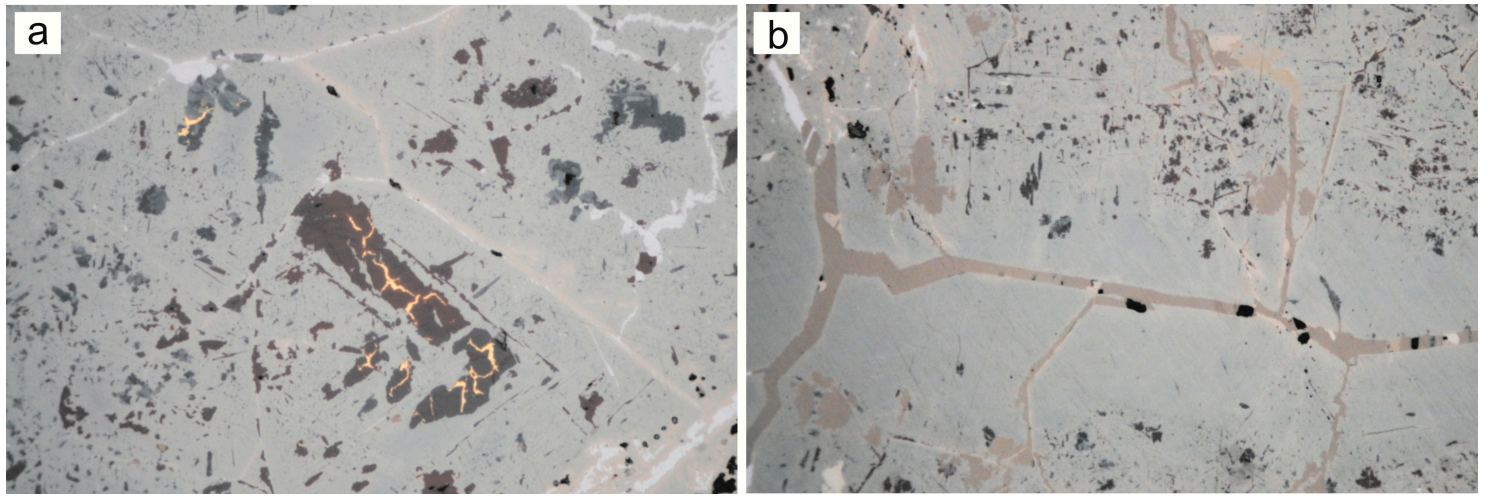

Figure 10. (a) Shrinkage cracks in deep-purple umangite-(g4) and bluish klockmannite-(g4) filled with native Au-(g4) (yellow). These minerals were likely deposited in response to dissolution of pre-existing selenides. Width $200 \mu \mathrm{m}$; (b) Network of shrinkage cracks in k-p s.-(g4) cemented by brownish eldragónite and bluish-white clausthalite. Width $500 \mu \mathrm{m}$.
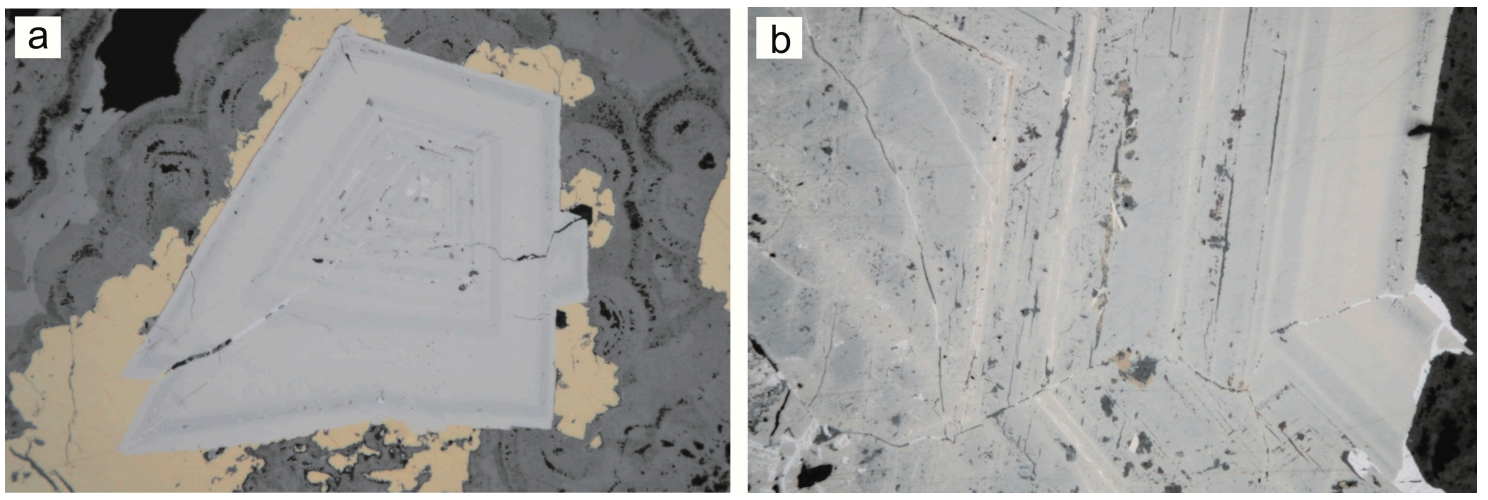

Figure 11. (a) Rhythmically zoned euhedral grain of k-p s.-(g5) with seven optically distinguishable zones representing $\mathrm{Cu}$-rich (blue-gray) and $\mathrm{Ni}-(\mathrm{Co})$-rich (grayish-cream) domains, overgrown by chalcopyrite (yellow). Width $1 \mathrm{~mm}$; (b) Color zonation pattern at the outermost rim of a k-p s.-(g5) grain. Discernible zones are distinguished by inclusion-rich bluish-grey and inclusion-poor creamy hues. Width $500 \mu \mathrm{m}$. 
Strongly brittle deformation (d3) caused either a finely branched system of tension cracks penetrating the colloform and crustiform-banded selenides or micro-brecciation (Figure 12a,b and Figure 13a,b). Subsequent late stage III selenide precipitation encompasses fracture-filling growth generation k-p s.-(g6) including (in the order of abundance) clausthalite-(g6), klockmannite-(g6), umangite-(g6), watkinsonite-(g6), eldragónite-(g6), eskebornite-(g6), quijarroite-(g6), hansblockite-(g6), phase "C"-(g6), petrovicite-(g6), grundmannite-(g6), penroseite-(g6), "Se-fletcherite"-(g6) (Figure 14, see Section 3.2.3), and native gold-(g6). Sharp edges of angular k-p s.-(g1)-(g6) fragments cemented by clausthalite are evidence that the fracture surfaces have not undergone significant corrosion. The younger $\mathrm{Cu}-\mathrm{Hg}-\mathrm{Pb}-\mathrm{Bi}-(\mathrm{g} 6)$ selenides are preferentially concentrated adjacent to older generations of watkinsonite, eldragónite, tiemannite, and clausthalite, which display signs of partial to complete dissolution. $\mathrm{Cu}-\mathrm{Hg}-\mathrm{Pb}-\mathrm{Bi}-(\mathrm{g} 6)$ selenides occur either as armored relics inside the older $\mathrm{k}-\mathrm{p}$ s. or in the surrounding clausthalite-(g6), frequently in association with subhedral to euhedral Co-rich penroseite-(g6). Polygonal grain shapes of clausthalite-(g6) and watkinsonite-(g6) prove their crystallization after fragmentation. Larger cavities of collapse breccia were sealed by dolomite-(g6). Minor amounts of clausthalite-(g6), watkinsonite-(g6), petrovicite-(g6), and grundmannite-(g6) were deposited at the surfaces of k-p s. aggregates as subhedral to euhedral grains and branching grain aggregates (Figure 15a). Isolated subhedral to euhedral aggregates of elongated k-p s. frequently contain remnants of skeletal watkinsonite-(g4) grains, which are locally dissolved or replaced by secondary alteration products (Figure 15b).

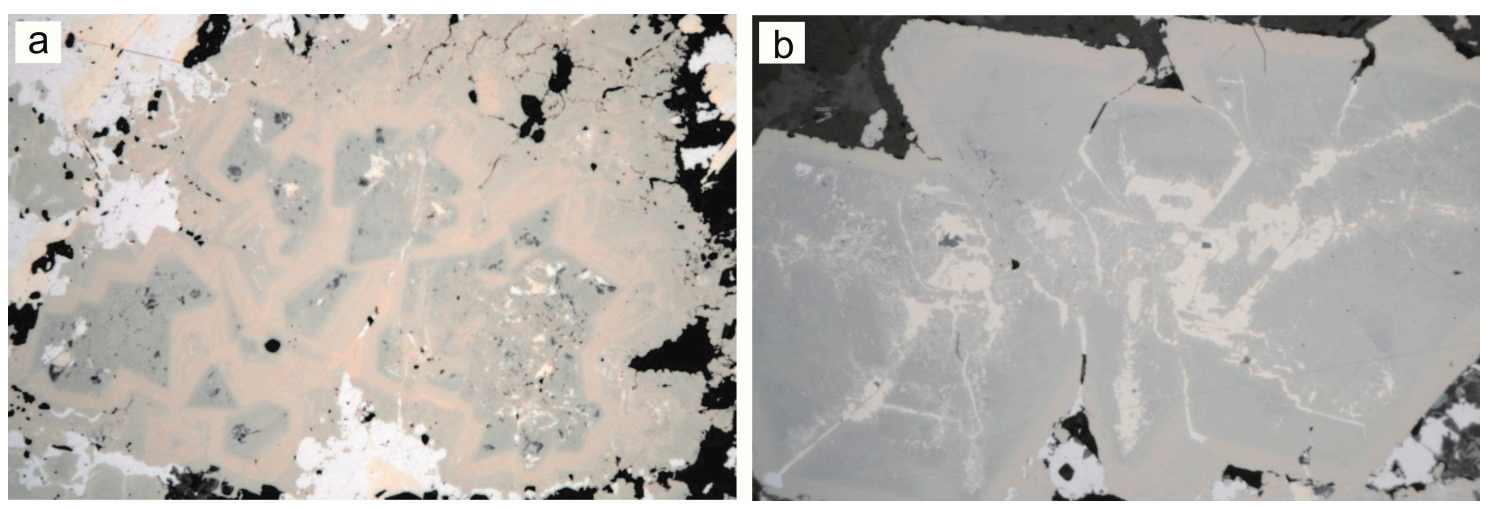

Figure 12. (a) Ni-Co-rich, inclusion-poor k-p s.-(g5) (pinkish-cream) overgrowing $\mathrm{Cu}$ - and inclusion-rich rich k-p s.-(g4) (blue-grey). Width $500 \mu \mathrm{m}$; (b) Armored relics of partly oriented, skeletal grains of watkinsonite in Cu-rich k-p s.-(g4) rimmed by Ni-Co-rich k-p s.-(g5). Width $200 \mu \mathrm{m}$.
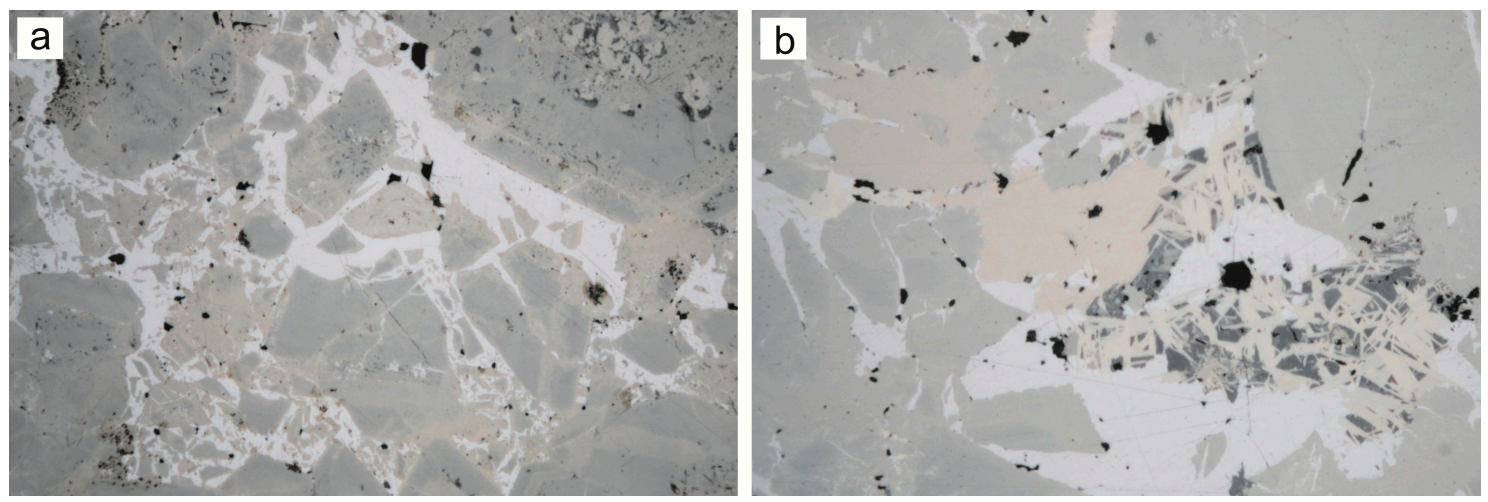

Figure 13. (a) Brittle deformation (d3) caused fragmentation of a k-p s.-(g1)-(g5) aggregate and subsequent cementation by fine-grained clausthalite. Width $200 \mu \mathrm{m}$; (b) Another fragmented aggregate that got cemented by various (g6)-selenides. Width $500 \mu \mathrm{m}$. 
Strong brittle deformation $(d 4)$ generated multiple micro-fractures preferentially parallel to the selvages and perpendicular to the selenium vein. As result, a finely branched system of tension cracks penetrated the vein and the siltstone host rock. Subsequently, $\mathrm{Cu}-\mathrm{Fe}-\mathrm{S}$ rich fluids infiltrated the El Dragón fault, giving rise to a widespread alteration of the earlier mineralization. Late stage IV fracture-fillings [mainly chalcopyrite-(g7), covellite-(g7), and, very subordinately, pyrite-(g7), marcasite-(g7), chalcocite-(g7), vaesite-(g7) and Au-(g7)] postdate the selenides and dolomite-(g6) gangue (Figures 11a and 16). Chalcopyrite-(g7) and other alteration products also filled large parts of the joint between the vein and the siltstone host rock. At the end of stage $I V$, the existing shrinkage cracks, micro-fractures, interstices, and highly porous selenide aggregates were successively invaded by strongly oxidizing fluids, which also attacked the newly precipitated sulfide cement to form goethite-(g7), and lepidocrocite-(g7). Pre-existing clausthalite that crystallized at the margins and outside the complex selenide structure was easily accessible for these fluids, which triggered its partial or complete replacement by a complicated mixture of extremely rare, fine-grained selenides-(g7) including klockmannite-(g7), athabascaite-(g7) (Figure 17), petř́čekite-(g7), krut'aite-(g7) (Figure 18), and native selenium-(g7) [4].

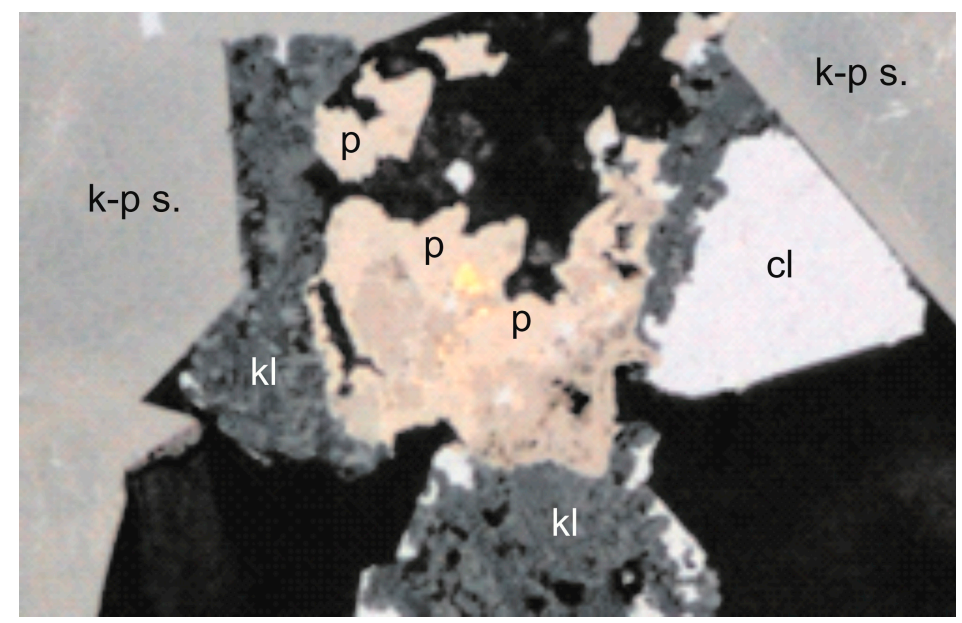

Figure 14. Armored relics of an unnamed Ni-Cu-Co selenide (pinkish grey, cf. Section 3.2.3) and native gold (yellow) enclosed by near-endmember penroseite (p), cementing together with klockmannite (kl) and clausthalite (cl) fragments of krut'aite-penroseite (k-p s.). Width $100 \mu \mathrm{m}$.
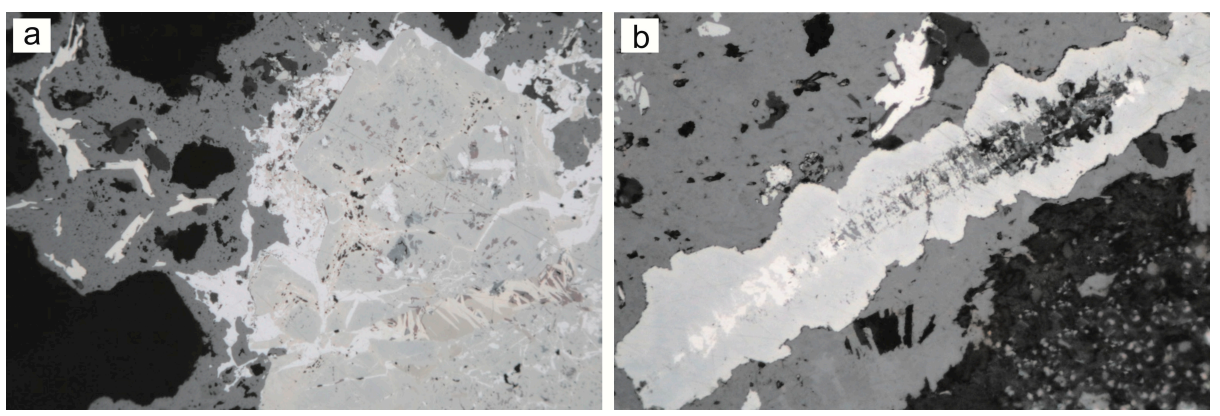

Figure 15. (a) Strongly fragmented, inclusion-rich k-p s.-(g4)-k-p s.-(g5) aggregate cemented by (g6)-selenides. Sub- to anhedral grains of watkinsonite-(g6) and clausthalite-(g6) crystallized outside the aggregate, predominantly between the grain boundaries of dolomite-(g6) (black), which itself is partly replaced by goethite-(g7-g8). Width $500 \mu \mathrm{m}$; (b) Elongated k-p s.-(g4)-k-p s.-(g5) aggregate containing remnants of skeletal watkinsonite-(g4), which have been partially replaced by alteration minerals or were dissolved. Width $200 \mu \mathrm{m}$. 
Post-selenide cataclasis (d5) cut through all previous mineralization and deformation structures and opened spaces between the selenium vein sections and the siltstone host rock. Ultimate stage $V$ of ongoing alteration in the oxidation zone encompasses numerous secondary minerals of growth generation (g8): favreauite, chalcomenite, schmiederite, molybdomenite, ahlfeldite, olsacherite, cobaltomenite, anglesite, linarite, alfredopetrovite, felsőbányaite, allophane, reevesite, malachite, aragonite, gypsum, and native selenium. Most of the dolomite-(g6) gangue was replaced by latest Fe-hydroxides-(g8) to form pseudomorphs. In contrast, the bulk of the watkinsonite-(g6) grains outside the composite structures remained stable, incrusted and protected by Fe-hydroxides-(g8) during late-stage alteration (cf. Figure 15a). For further information, see [3,8,14,17].

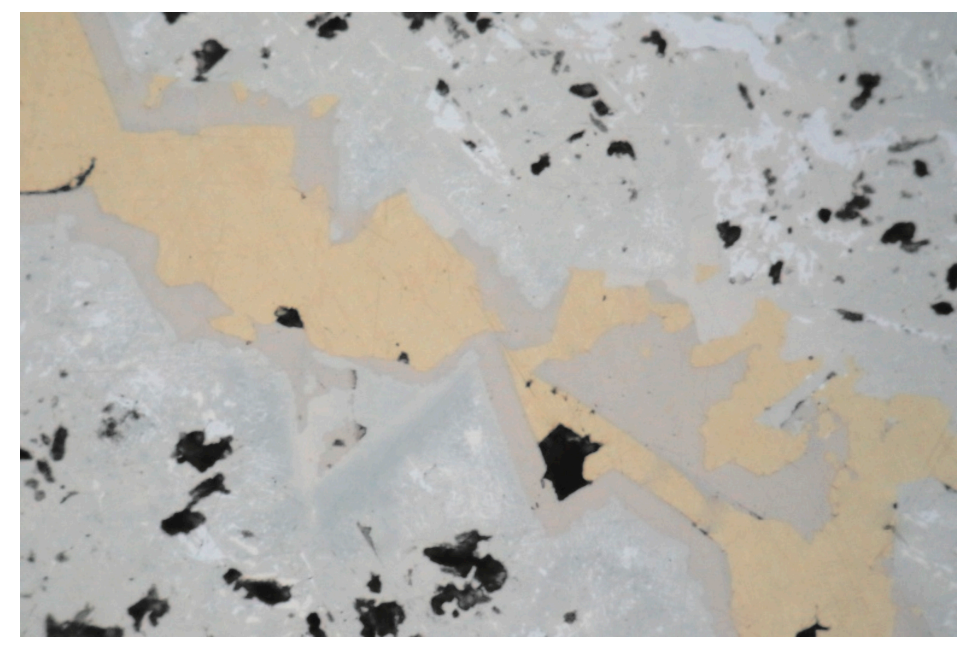

Figure 16. Chalcopyrite-(g7) (yellow) cementing and corroding the Ni-Co-rich margins of two facing k-p s.-(g5) aggregates rich in clausthalite inclusions. The reaction zone consists of pink vaesite-pyrite solid solutions and $\mathrm{Cu}-\mathrm{Co}$-rich penroseite and, rarely, minute grains of trogtalite. Width $200 \mu \mathrm{m}$.

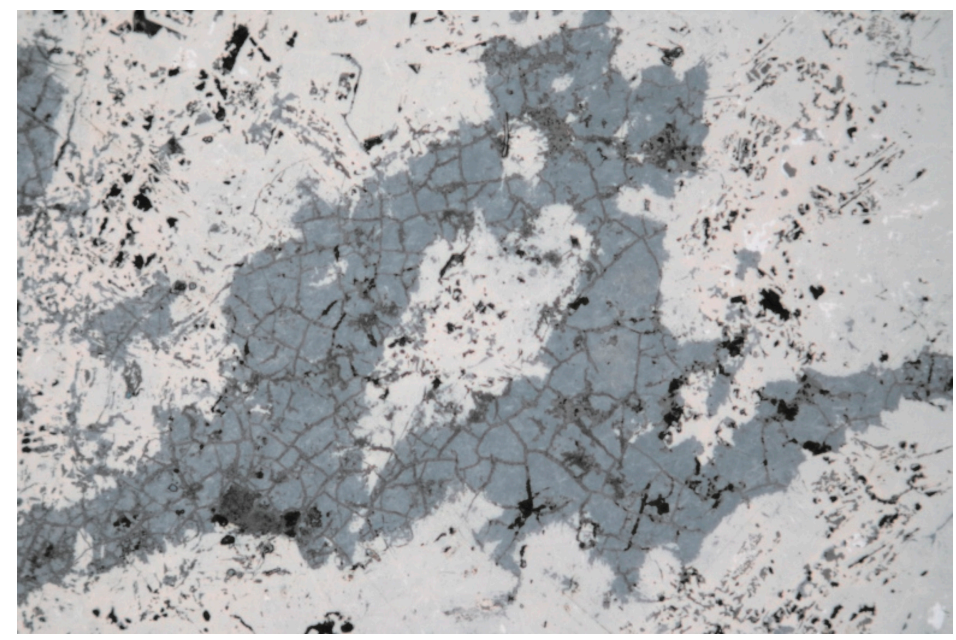

Figure 17. Fine-grained athabascaite-(g7) (bluish), which shows a network of shrinking cracks, penetrates k-p s.-(g3). Width $500 \mu \mathrm{m}$. 

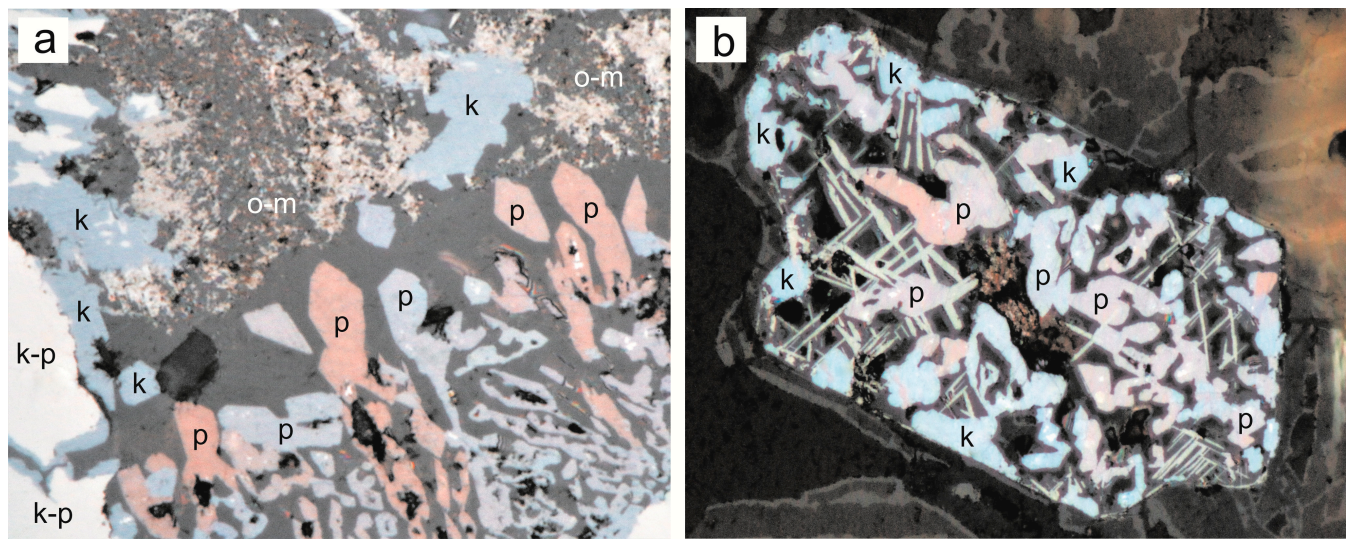

Figure 18. (a) Fragments of krut'aite-penroseite (k-p) cemented and partially replaced by skeletal palisades of subhedral grains of petříčekite-(g7) (p), krut'aite-(g7) (k), and olsacherite-molybdomenite-(g8) (o-m), Plane polarized incident light. Width $100 \mu \mathrm{m}$; (b) Skeletal petříčekite-(g7), krut'aite-(g7), and acicular native selenium-(g7) pseudomorph after clausthalite, surrounded by allophane-(g8) and goethite-(g8). Plane polarized incident light. Width $130 \mu \mathrm{m}$.

Figure 19 shows schematically the formation of various stage $V$ secondary minerals in relation to eleven primary mineral associations representing the potential source of the corresponding elements.

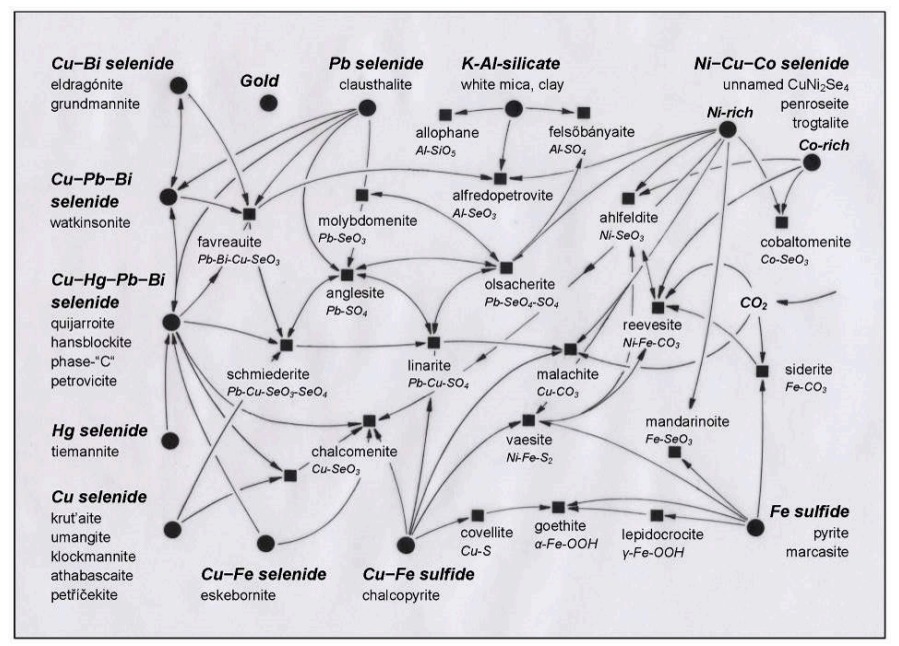

Figure 19. Paragenetic scheme of the formation of secondary minerals from eight primary selenide and two sulfide mineral assemblages, and one K-Al-silicate mineral association (modified after [14]).

\subsubsection{Mineral Chemistry}

In the following we report and discuss compositional data for native $\mathrm{Au}$, the selenides, and the sulfides precipitated in stage $I V$, roughly considering their genetic sequence (cf. Figure 4). Formula proportions given for individual minerals refer to mean compositions.

Early gold is nearly pure $\mathrm{Au}$, containing only between 0.7 and $0.8 \mathrm{wt} \% \mathrm{Ag}\left(\mathrm{Au}_{0.99} \mathrm{Ag}_{0.01}\right)$. Late deposited gold has substituted a little more $\mathrm{Ag}$ (1.1-2.1 wt \%; $\mathrm{Au}_{0.98} \mathrm{Ag}_{0.02}$ ).

The massive aggregates of the krut'aite-penroseite solid-solution series show a wide range in composition in terms of $\mathrm{Cu}-\mathrm{Ni}-\mathrm{Co}$ proportions (Figure 20). They commonly span the range (mole $\%)$ $\mathrm{Kru}_{70} \mathrm{Pen}_{27} \mathrm{Tro}_{3}$ (Table 1, ana\# 1) to $\mathrm{Kru}_{40} \mathrm{Pen}_{42} \mathrm{Tro}_{18}$ (Table 1, ana\# 2) and contain $<0.1 \mathrm{wt} \% \mathrm{~S}$, with the bulk of the ore plotting in the krut'aite field. Figure 21 presents the results of an electron-microprobe traverse from the rim towards the core of a k-p s.-(g5) grain showing oscillatory zoning. 


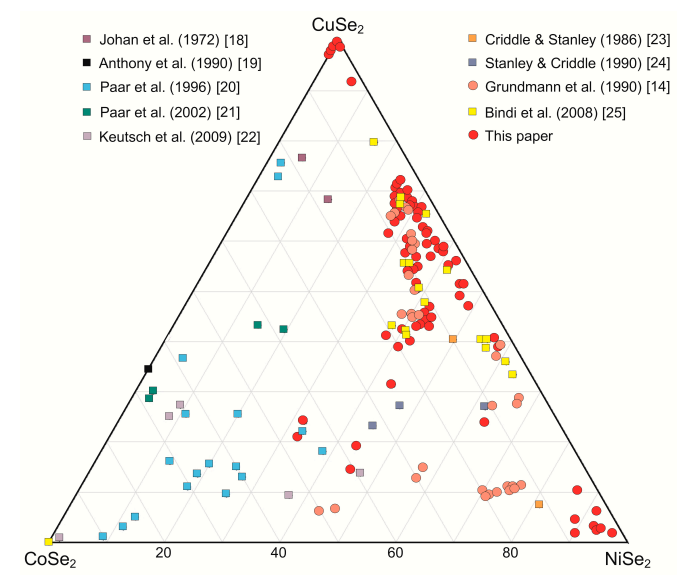

Figure 20. $\mathrm{CuSe}_{2}-\mathrm{NiSe}_{2}-\mathrm{CoSe}_{2}$ ternary diagram showing the extent of compositional variation of minerals in the system krut'aite-penroseite-trogtalite from El Dragón and other occurrences [14,18-25]. Note the unique composition of late penroseite and krut'aite close to end-member composition.

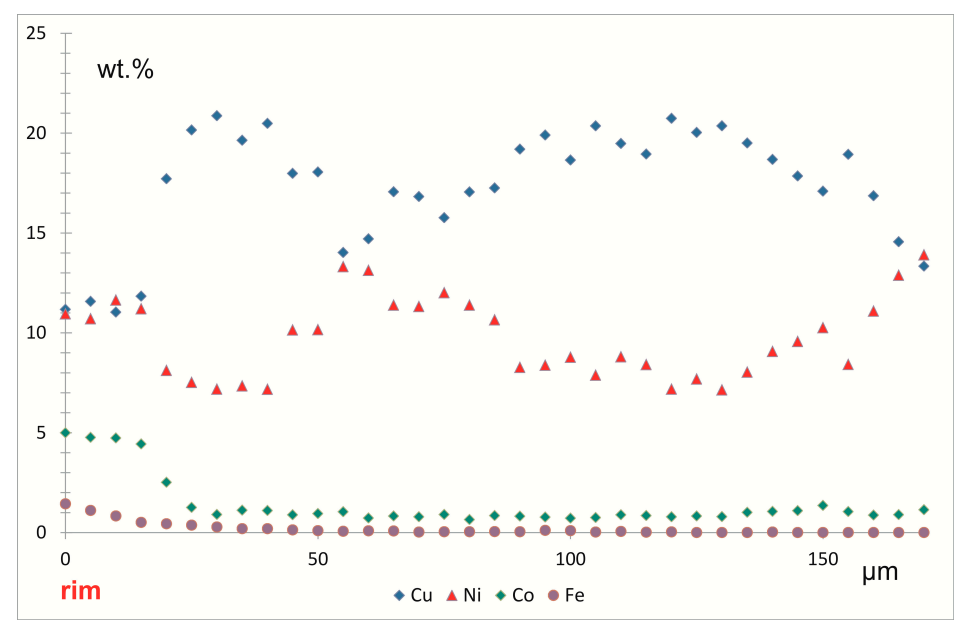

Figure 21. Variation of $\mathrm{Cu}, \mathrm{Ni}, \mathrm{Co}$, and Fe concentrations in a rhythmically zoned k-p s.-(g5) grain from the outermost rim towards the core. The 170- $\mu \mathrm{m}$-long electron-microprobe traverse (spot distance $5 \mu \mathrm{m}$, beam size $1 \mu \mathrm{m}$ ) reflects the narrow alternation of the zones of relative $\mathrm{Cu}$ and Ni enrichment and shows that $\mathrm{Co}$ and Fe became most enriched during the final stage of grain growth.

Compositions closer to the penroseite end-member refer to grains: (a) associated with $\mathrm{Cu}-\mathrm{Hg}$ Bi-Pb selenides (Table 1, ana\# 3); (b) deposited in fractures; and (c) crystallized within marginal domains in k-p s.-(g5) neighboring chalcopyrite/vaesite (Table 1, ana\# 4-5; cf. Figure 16) or athabascaite (cf. Figure 17). Some minute penroseite-(g6) grains deposited, together with late clausthalite, in interstices and in intergrown acicular grains of stage $\mathrm{III} \mathrm{Cu}-\mathrm{Hg}-\mathrm{Bi}-\mathrm{Pb}$ selenides display near end-member penroseite composition not yet reported from any other locality (cf. Figure 20; Table 1, ana\# 6-7; mean formula $\left.\left(\mathrm{Ni}_{0.95} \mathrm{Co}_{0.03} \mathrm{Cu}_{0.02} \mathrm{Fe}_{0.01}\right)_{\Sigma 1.01} \mathrm{Se}_{1.98}, n=6\right)$. Ni-Cu-rich trogtalite $\left[\left(\mathrm{Co}_{0.44} \mathrm{Ni}_{0.32} \mathrm{Cu}_{0.21} \mathrm{Fe}_{0.01}\right)_{\Sigma 0.98}\left(\mathrm{Se}_{2.01} \mathrm{~S}_{0.01}\right)_{\Sigma 2.02}\right.$; Table 1, ana\# 89] was only observed within the k-p s.-g(5) contact aureole with the chalcopyrite-vaesite veinlet (cf. Figure 16), probably formed by dissolution-reprecipitation in response to the interaction of the S-rich fluid with the Co-rich margin of the k-p s.-g(5) grain during stage $I V$. A Ni-Cu-Co selenide occurring as small grains inside penroseite-(g6) likely represents a new mineral (cf. Figure 14). Electron-microprobe analyses of two grains (Table 1, ana\# 10-11) yielded the mean empirical formula $\mathrm{Cu}_{0.98} \mathrm{Ni}_{1.64} \mathrm{Co}_{0.37} \mathrm{~Pb}_{0.01} \mathrm{Se}_{3.97} \mathrm{~S}_{0.03}$ (normalized to 7 apfu). The ideal formula would be $\mathrm{CuNi}_{2} \mathrm{Se}_{4}$, which chemically corresponds to the Se-analog of fletcherite, $\mathrm{CuNi}_{2} \mathrm{~S}_{4}$. 
Table 1. Representative results of electron-microprobe analyses of minerals in the system krut'aitepenroseite-trogtalite und unnamed $\mathrm{CuNi}_{2} \mathrm{Se}_{4}$.

\begin{tabular}{cccccccccccc}
\hline Element/\# & $\mathbf{1}$ & $\mathbf{2}$ & $\mathbf{3}$ & $\mathbf{4}$ & $\mathbf{5}$ & $\mathbf{6}$ & $\mathbf{7}$ & $\mathbf{8}$ & $\mathbf{9}$ & $\mathbf{1 0}$ & $\mathbf{1 1}$ \\
\hline $\mathrm{Cu}(\mathrm{wt} \%)$ & 20.36 & 13.33 & 4.03 & 10.45 & 5.32 & 0.54 & 0.78 & 5.64 & 6.57 & 12.62 & 12.54 \\
$\mathrm{~Pb}$ & 0 & 0 & 0.15 & 0 & 0 & 0.20 & 0.10 & 0 & 0 & 0.35 & 0.65 \\
$\mathrm{Fe}$ & 0 & 0 & 0.28 & 0 & 0.40 & 0 & 0.36 & 0.28 & 0.10 & 0 & 0.05 \\
$\mathrm{Co}$ & 0.79 & 1.14 & 10.88 & 0.68 & 9.57 & 0.43 & 0.63 & 12.04 & 11.88 & 3.72 & 5.00 \\
$\mathrm{Ni}$ & 7.14 & 13.91 & 12.45 & 16.47 & 11.70 & 25.90 & 26.06 & 8.69 & 8.75 & 19.73 & 18.96 \\
$\mathrm{~S}$ & 0 & 0 & 0.07 & 0.03 & 0.12 & 0.07 & 0.08 & 0.10 & 0.10 & 0.15 & 0.19 \\
$\mathrm{Se}$ & 71.79 & 72.07 & 71.92 & 71.88 & 72.23 & 72.23 & 71.88 & 72.72 & 72.23 & 63.26 & 62.92 \\
Total & 100.24 & 100.45 & 99.78 & 100.02 & 99.33 & 99.37 & 99.89 & 99.48 & 99.62 & 99.83 & 100.30 \\
\hline
\end{tabular}

Notes: $0=$ below detection limit; $1-11$ refer to the mineral-analysis numbers mentioned in the text.

Clausthalite was never observed representing ideal PbSe. Instead, it has incorporated minor amounts of many cations and anions present in the mineralizing fluids. Maximum concentrations (in wt \%) measured in clausthalite amount to: $\mathrm{Cu}=3.4, \mathrm{Ag}=0.5, \mathrm{Hg}=0.2, \mathrm{Ni}=0.4, \mathrm{Bi}=1.1$, and $\mathrm{S}=1.9$. Tiemannite is notoriously rich in Cd [4.4-6.0 wt \%; $\left.\left(\mathrm{Hg}_{0.88} \mathrm{Cd}_{0.12}\right)_{\Sigma 1.00} \mathrm{Se}_{1.00}\right]$; from the other elements sought is only Fe occasionally above detection limit (0.0-0.3 wt \%). Representative microprobe data for eskebornite $\left.\mathrm{Cu}_{1.00}\left(\mathrm{Fe}_{0.99} \mathrm{Ni}_{0.01}\right)_{\Sigma 1.00} \mathrm{Se}_{1.99}\right)$, klockmannite $\left.\left(\mathrm{Cu}_{0.99} \mathrm{Ni}_{0.01}\right)_{\Sigma 1.00} \mathrm{Se}_{0.99}\right)$, and umangite $\left(\mathrm{Cu}_{2.95} \mathrm{Ni}_{0.05} \mathrm{Co}_{0.01}\right)_{\Sigma 3.01} \mathrm{Se}_{1.99}$ are listed in Table 2, demonstrating that all these species are poor in $\mathrm{S}$ and contain only small concentrations of non-ideal cations, usually the omnipresent Ni. Late-formed athabascaite $\left.\left(\mathrm{Cu}_{4.83} \mathrm{Ni}_{0.06} \mathrm{Co}_{0.05} \mathrm{Fe}_{0.02} \mathrm{~Pb}_{0.01} \mathrm{Ag}_{0.01}\right)_{\Sigma 4.98}\left(\mathrm{Se}_{2.06} \mathrm{~S}_{1.96}\right)_{\Sigma 5.02}\right)$, in contrast, is rich in $\mathrm{S}$ and may contain minor concentrations of several non-ideal cations (cf. Table 1, ana\# 7-8). Actually, this $\mathrm{Cu}$ mineral likely represents a solid solution intermediate between athabascaite and its yet unknown S-analog, ideally $\mathrm{Cu}_{5} \mathrm{~S}_{4}$.

Table 2. Representative results of electron-microprobe spot analyses of eskebornite, klockmannite, umangite, and athabascaite- $\mathrm{Cu}_{5} \mathrm{~S}_{4}$ solid solutions.

\begin{tabular}{ccccccccc}
\hline Element/\# & $\mathbf{1}$ & $\mathbf{2}$ & $\mathbf{3}$ & $\mathbf{4}$ & $\mathbf{5}$ & $\mathbf{6}$ & $\mathbf{7}$ & $\mathbf{8}$ \\
\hline $\mathrm{Cu}(\mathrm{wt} \%)$ & 23.43 & 22.42 & 43.55 & 44.99 & 52.60 & 54.66 & 56.10 & 57.19 \\
$\mathrm{Ag}$ & 0.04 & 0.04 & 0.85 & 0.09 & 0 & 0 & 0.17 & 0.06 \\
$\mathrm{Hg}$ & 0 & 0.23 & 0 & 0 & 0 & 0.26 & 0 & 0 \\
$\mathrm{~Pb}$ & 0.07 & 0.11 & 0.05 & 0 & 0 & 0.09 & 0.17 & 0.61 \\
$\mathrm{Fe}$ & 19.99 & 19.74 & 0 & 0 & 0.03 & 0 & 0.33 & 0.18 \\
$\mathrm{Co}$ & 0 & 0.04 & 0.04 & 0.16 & 0.21 & 0 & 0.65 & 0.19 \\
$\mathrm{Ni}$ & 0 & 0.43 & 0.34 & 0.73 & 1.49 & 0.10 & 0.89 & 0.37 \\
$\mathrm{Bi}$ & 0 & 0.16 & 0 & 0 & 0 & 0.13 & 0.22 & 0.12 \\
$\mathrm{~S}$ & 0.05 & 0.03 & 0.19 & 0.02 & 0 & 0 & 11.93 & 11.08 \\
$\mathrm{Se}$ & 56.55 & 56.29 & 54.89 & 54.51 & 45.26 & 44.96 & 29.14 & 30.48 \\
$\mathrm{Total}$ & 100.13 & 99.49 & 99.84 & 99.99 & 99.60 & 100.20 & 100.12 & 99.83 \\
\hline
\end{tabular}

Notes: 0 = below detection limit; $1-2$ = eskebornite; $3-4=$ klockmannite; $5-6=$ umangite; $7-8=\mathrm{Cu}_{5} \mathrm{Se}_{4}-\mathrm{Cu}_{5} \mathrm{~S}_{4}$ solid solutions. See text for further explanations.

Compositional data for the $\mathrm{Cu}-\mathrm{Bi}, \mathrm{Cu}-\mathrm{Pb}-\mathrm{Bi}$, and $\mathrm{Cu}-\mathrm{Hg}-\mathrm{Pb}-\mathrm{Bi}$ selenides grundmannite $\mathrm{Cu}_{0.99}\left(\mathrm{Bi}_{0.91} \mathrm{~Pb}_{0.02}\right)_{\Sigma 0.93} \mathrm{Se}_{2.08}$, eldrágonite $\left(\mathrm{Cu}_{5.71} \mathrm{Fe}_{0.28} \mathrm{Ni}_{0.04} \mathrm{Ag}_{0.01}\right)_{\Sigma 6.04} \mathrm{Bi}_{1.01} \mathrm{Se}_{5.96}$, watkinsonite $\left.\mathrm{Cu}_{1.53} \mathrm{Ag}_{0.44} \mathrm{Hg}_{0.08} \mathrm{Ni}_{0.02}\right)_{\Sigma 2.07} \mathrm{~Pb}_{1.08} \mathrm{Se}_{3.88}$, hansblockite $\left(\mathrm{Cu}_{0.68} \mathrm{Hg}_{0.27} \mathrm{Ag}_{0.03} \mathrm{Ni}_{0.01}\right)_{\Sigma 0.99}\left(\mathrm{Bi}_{0.69} \mathrm{~Pb}_{0.31}\right)_{\Sigma 1.00}$ $\mathrm{Se}_{2.01}$, quijarroite $\left(\mathrm{Cu}_{5.84} \mathrm{Ag}_{0.26}\right)_{\Sigma 6.10}\left(\mathrm{Hg}_{1.06} \mathrm{Ni}_{0.07} \mathrm{Co}_{0.01}\right)_{\Sigma 1.14} \mathrm{~Pb}_{2.27} \mathrm{Bi}_{3.68} \mathrm{Se}_{11.81}$, petrovicite $\left(\mathrm{Cu}_{2.97} \mathrm{Ag}_{0.04}\right)_{\Sigma 3.01} \mathrm{Hg}_{0.99} \mathrm{~Pb}_{0.99} \mathrm{Bi}_{1.03} \mathrm{Se}_{4.98}$, and unnamed phase " $\mathrm{C}$ " (empirical formula $\mathrm{Cu}_{4} \mathrm{~Pb}_{2} \mathrm{HgBi}_{4} \mathrm{Se}_{11}$ ) are provided in [5-7]. A selection of results of representative electron-microprobe analyses of these species is given in Table 3. These data document the paucity of all species in $\mathrm{S}$ and that watkinsonite constitutes the most important host of Ag. The formula of the most Ag-rich watkinsonite measured in this study is $\left.\mathrm{Cu}_{1.02} \mathrm{Ag}_{0.89} \mathrm{Hg}_{0.11} \mathrm{Ni}_{0.01}\right)_{\Sigma 2.03} \mathrm{~Pb}_{1.10} \mathrm{Se}_{3.89}$ (Table 3, ana\# 6), implying the possible existence of the Ag-analog of watkinsonite with the ideal formula $\mathrm{Ag}_{2} \mathrm{PbBi}_{4} \mathrm{Se}_{8}$. 
As all earlier crystallized selenides are very poor in $\mathrm{S}$ (except of athabascaite), the stage (IV) sulfides are poor in Se. The Fe sulfides pyrite $\left(\mathrm{Fe}_{0.96} \mathrm{Ni}_{0.02} \mathrm{Cu}_{0.01}\right)_{\Sigma 0.99}\left(\mathrm{~S}_{2.00} \mathrm{Se}_{0.01}\right)_{\Sigma 2.01}$ and marcasite $\left(\mathrm{Fe}_{0.99} \mathrm{Ni}_{0.01}\right)_{\Sigma 01.00} \mathrm{~S}_{2.00}$ contain always minor concentrations of the omnipresent $\mathrm{Cu}$ (pyrite $=0.1-2.3 \mathrm{wt} \%$, marcasite $<0.1 \mathrm{wt} \%), \mathrm{Ni}(0.2-2.8 \mathrm{wt} \%)$ and $\mathrm{Se}(0.1-1.8 \mathrm{wt} \%)$. Interestingly, largest concentrations of $\mathrm{Cu}$, $\mathrm{Ni}, \mathrm{Co}$, and Se are confined to the immediate contact of both sulfides with k-p s.-g(5) (Table 4, ana\# 1-2), implying that these four elements sourced from corroded pre-existing krut'aite-penroseite. Chalcopyrite $\mathrm{Cu}_{0.99} \mathrm{Fe}_{1.01}\left(\mathrm{~S}_{2.00} \mathrm{Se}_{0.01}\right)_{\Sigma 2.01}$ is poor in non-stoichiometric elements, except of containing between 0.5 and $1 \mathrm{wt} \%$ Se. Covellite $\left(\mathrm{Cu}_{0.98} \mathrm{Fe}_{0.02}\right)_{\Sigma 1.00}\left(\mathrm{~S}_{0.97} \mathrm{Se}_{0.02}\right)_{\Sigma 0.99}$ is relatively little richer in non-stoichiometric components, with the following maximum concentrations (wt \%): $\mathrm{Ag}=0.6, \mathrm{Fe}=1.4, \mathrm{Ni}=0.3$, and Se $=2.9$ (Table 4, ana\# 3). The chemically most interesting sulfide is that forming the reaction zone between chalcopyrite and k-p s.-g(5) (cf. Figure 16). This mineral is relatively homogeneous in composition and represents an intermediate member of the vaesite-pyrite solid solution series, with all compositions plotting in the vaesite field. In addition to the major components $\mathrm{Ni}$ and $\mathrm{Fe}$, it has incorporated minor $\mathrm{Cu}(0.3-0.8 \mathrm{wt} \%)$, Co (3.5-4.7 wt \%), and Se (0.5-2.3 wt \%) (Table 4, ana\# 5-6), The mean formula of vaesite from El Drágon is $\left(\mathrm{Ni}_{0.49} \mathrm{Fe}_{0.40} \mathrm{Co}_{0.08} \mathrm{Cu}_{0.01}\right)_{\Sigma 0.98}\left(\mathrm{~S}_{2.00} \mathrm{Se}_{0.02}\right)_{\Sigma 2.02}$.

Table 3. Representative results of electron-microprobe spot analyses of $\mathrm{Cu}-\mathrm{Bi}, \mathrm{Cu}-\mathrm{Pb}-\mathrm{Bi}$, and $\mathrm{Cu}-\mathrm{Hg}-\mathrm{Pb}-\mathrm{Bi}$ selenides.

\begin{tabular}{ccccccccccccc}
\hline Element/\# & $\mathbf{1}$ & $\mathbf{2}$ & $\mathbf{3}$ & $\mathbf{4}$ & $\mathbf{5}$ & $\mathbf{6}$ & $\mathbf{7}$ & $\mathbf{8}$ & $\mathbf{9}$ & $\mathbf{1 0}$ & $\mathbf{1 1}$ & $\mathbf{1 2}$ \\
\hline $\mathrm{Cu} \mathrm{(wt} \mathrm{\% )}$ & 14.80 & 14.79 & 33.95 & 34.12 & 6.07 & 3.49 & 8.95 & 9.45 & 13.00 & 13.47 & 15.67 & 14.99 \\
$\mathrm{Ag}$ & 0 & 0 & 0.21 & 0.08 & 1.33 & 5.16 & 1.29 & 0.58 & 1.49 & 0.77 & 0.15 & 0.84 \\
$\mathrm{Hg}$ & 0 & 0.25 & 0 & 0 & 0.56 & 1.21 & 11.55 & 11.28 & 7.76 & 7.77 & 16.56 & 16.67 \\
$\mathrm{~Pb}$ & 1.37 & 1.25 & 0 & 0 & 12.09 & 12.34 & 13.78 & 13.45 & 16.97 & 16.79 & 17.21 & 17.24 \\
$\mathrm{Fe}$ & 0 & 0 & 1.65 & 1.69 & 0 & 0 & 0 & 0 & 0 & 0 & 0 & 0 \\
$\mathrm{Co}$ & 0 & 0 & 0 & 0.11 & 0 & 0 & 0.06 & 0 & 0.05 & 0 & 0 & 0 \\
$\mathrm{Ni}$ & 0 & 0.05 & 0.07 & 0.48 & 0.05 & 0.14 & 0.40 & 0.05 & 0.23 & 0 & 0 & 0 \\
$\mathrm{Bi}$ & 44.62 & 44.90 & 19.82 & 19.64 & 44.83 & 43.86 & 30.71 & 31.50 & 27.45 & 27.86 & 17.90 & 17.80 \\
$\mathrm{~S}$ & 0 & 0 & 0 & 0 & 0 & 0 & 0 & 0 & 0 & 0 & 0 & 0 \\
$\mathrm{Se}$ & 39.15 & 38.98 & 44.18 & 44.39 & 34.71 & 33.95 & 33.99 & 33.84 & 33.46 & 33.39 & 32.60 & 32.41 \\
$\mathrm{Total}$ & 99.95 & 100.22 & 99.87 & 100.51 & 99.63 & 100.03 & 100.72 & 100.15 & 100.39 & 100.04 & 100.10 & 99.95 \\
\hline
\end{tabular}

Notes: 0 = below detection limit; $1-2$ = grundmannite; $3-4$ = eldrágonite; 5-6 = watkinsonite; $7-8$ = hansblockite; 9-10 = quijarroite, $11-12$ = petrovicite. See text for further explanations.

Table 4. Representative results of electron-microprobe spot analyses of sulfides and selenides formed during stage $I V$.

\begin{tabular}{ccccccccccc}
\hline Element/\# & $\mathbf{1}$ & $\mathbf{2}$ & $\mathbf{3}$ & $\mathbf{4}$ & $\mathbf{5}$ & $\mathbf{6}$ & $\mathbf{7}$ & $\mathbf{8}$ & $\mathbf{9}$ & $\mathbf{1 0}$ \\
\hline $\mathrm{Cu}(\mathrm{wt} \%)$ & 0.41 & 0.07 & 64.63 & 64.07 & 0.48 & 0.52 & 28.58 & 28.51 & 28.31 & 28.160 .19 \\
$\mathrm{Ag}$ & 0 & 0 & 0.51 & 0.52 & 0 & 0 & 0.05 & 0.05 & 0.02 & 0.19 \\
$\mathrm{Hg}$ & 0 & 0 & 0 & 0 & 0 & 0 & 0 & 0 & 0 & 0 \\
$\mathrm{~Pb}$ & 0 & 0 & 0 & 0 & 0 & 0 & 0 & 0 & 0 & 0 \\
$\mathrm{Fe}$ & 42.92 & 45.71 & 1.21 & 1.16 & 18.24 & 16.52 & 0 & 0 & 0 & 0 \\
$\mathrm{Co}$ & 0.19 & 0.11 & 0.04 & 0 & 4.39 & 3.78 & 0.03 & 0.02 & 0.14 & 0.020 .06 \\
$\mathrm{Ni}$ & 2.82 & 0.61 & 0.09 & 0.09 & 23.33 & 25.60 & 0.09 & 0.09 & 0.27 & 0.06 \\
$\mathrm{As}$ & 0 & 0.06 & 0 & 0 & 0 & 0 & 0 & 0 & 0 & 0 \\
$\mathrm{Bi}$ & 0 & 0 & 0 & 0 & 0 & 0 & 0 & 0 & 0 & 0 \\
$\mathrm{~S}$ & 52.35 & 53.27 & 32.04 & 31.81 & 52.81 & 51.38 & 0.03 & 0.02 & 0.02 & 0.02 \\
$\mathrm{Se}$ & 1.30 & 0.42 & 2.11 & 2.51 & 0.59 & 2.19 & 71.39 & 71.50 & 71.04 & 71.87 \\
$\mathrm{Total}$ & 99.49 & 100.25 & 100.72 & 100.16 & 99.20 & 99.98 & 100.17 & 99.88 & 99.79 & 100.32 \\
\hline
\end{tabular}

Notes: 0 = below detection limit; 1 = pyrite; 2 = marcasite; $3-4$ = covellite; $5-6$ = vaesite; $7-8$ = petř́ičekite; $9-10=$ krut'aite. See text for further explanations.

Selenides formed during stage $I V$ include petříčekite $\mathrm{Cu}_{0.99} \mathrm{Se}_{2.00}$ and krut'aite $\left(\mathrm{Cu}_{0.98} \mathrm{Ni}_{0.01}\right)_{\Sigma 0.99} \mathrm{Se}_{2.00}$ of almost ideal composition CuSe 2 (Table 4, ana\# 7-10). El Drágon constitutes the occurrence of penroseite and krut'aite closest to end-member composition known to date (cf. Figure 20). 


\subsection{Petrography of Black Shale Country Rock}

Hand specimens of black shale from surface outcrops are dark grey to black. The finest grained structure is diagenetically consolidated and resistant to water, but strongly porous. Grain size ranges between 0.001 and $0.05 \mathrm{~mm}$, classifying it as silty slate. Due to the weathering of pyrite the joint surfaces are rusty brown (Figure 22a). Brittle deformation caused finely divided network of joints parallel and transverse to stratification often filled with whitish clay and minor chalcopyrite (Figure 22a). Thinly stratified plane lamination is dotted stained with flaky white mica. A thin section perpendicular to the sedimentary bedding displays the fine alternation of layers richer and poorer in pyrite (Figure 22b).

Main components are (estimated volume percentages in parentheses): white mica (70\%), quartz $(10 \%)$, pyrite $(5 \%)$; minor components $(<1 \%)$ are amphibole, tourmaline, chalcopyrite, bornite, wurtzite and covellite. Matrix cement consists of clay (15\%). The $\mathrm{Cu}-, \mathrm{Ni}-, \mathrm{Fe}-$ and $\mathrm{Zn}$-bearing sulfide aggregates are characterized by partial dissolution from their margins inwards and by a flame-like intergrowth of chalcopyrite and bornite. Pyrite occurs in various forms, as lenses composed of fine-grained botryoidal or framboidal aggregates subparallel to the sedimentary bedding, and as crack fillings. The framboidal pyrite mineralization strongly resembles that of the Central European Permian Kupferschiefer in Germany and Poland (cf. [26]). From these, the pyrite cementing the framboids in botryoidal grains (cf. Figure 22e) consistently contains $\mathrm{Cu}(0.1-0.8 \mathrm{wt} \%$ ), Ni and $\mathrm{Co}$ (both $0.02-0.1 \mathrm{wt} \%$ ) above their microprobe detection limits of $\sim 200 \mathrm{ppm}$. In other pyrites and the $\mathrm{Cu}-\mathrm{Zn}$ sulfides, $\mathrm{Co}$ and $\mathrm{Ni}$ are below their detection limits. The same holds for Se, which is normally below detection limit in all these sulfides ( $600 \mathrm{ppm})$.

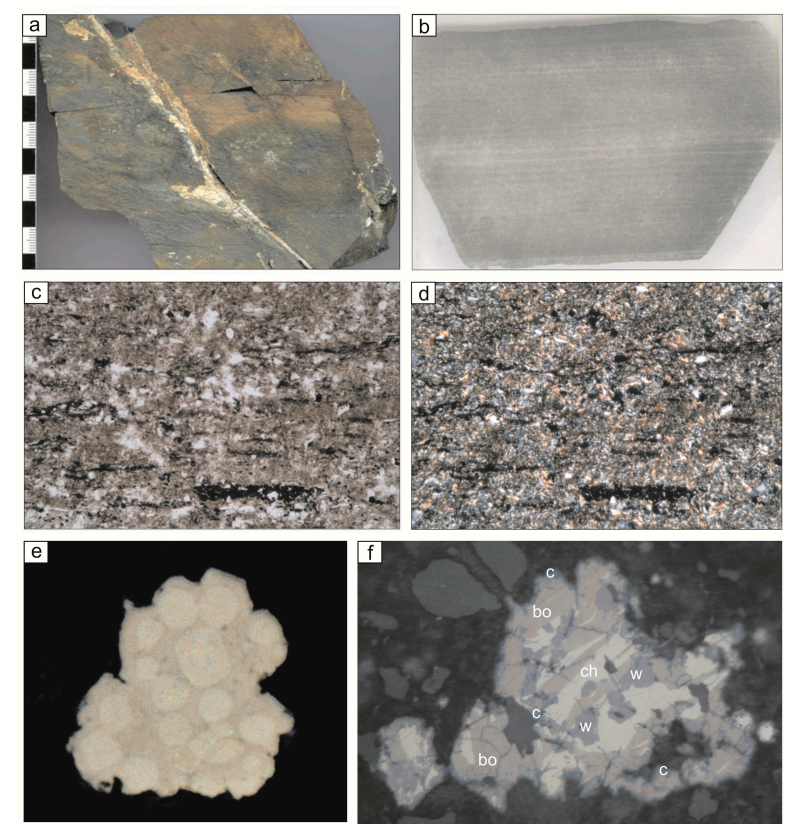

Figure 22. (a) Representative hand specimen of black shale, crosscut perpendicular to the sedimentary bedding, collected at the hanging wall of the El Dragón mine. A diagonal fracture is filled with clay and minor chalcopyrite; (b) Thin section oriented crosscut perpendicular to the sedimentary bedding of the thinly stratified black shale. Bright layers are rich in white mica, dark layers are rich in clay. Width $3 \mathrm{~cm}$; (c) Detailed view of (b) showing fine-grained white mica and clay. The horizontally layered opaque lenses mainly consist of extremely fine-grained botryoidal (framboidal) pyrite and minor copper sulfides. Thin section, 1 polarizer, width $1 \mathrm{~mm}$; (d) Same as (c), but with crossed polarizers; (e) Partly corroded accessory aggregate of pyrite framboids cemented by pyrite (for further details see text). Polished section, width $30 \mu \mathrm{m}$; (f) Corroded (embayed) accessory aggregate of copper and zinc sulfides including chalcopyrite (ch), bornite (bo), wurtzite (w) and covellite (c). Polished section, width $100 \mu \mathrm{m}$. 


\section{Discussion}

\subsection{Sources of Elements}

From the rocks neighboring the Se-bearing structure at El Dragón, the Ordovician phyllites, the (possibly Devonian) Black shales, and the Tertiary lavas/tuffs may potentially contain elevated Se concentrations. None of these rocks have been systematically studied for trace-element abundances as well as for their mineralogical composition. The black-shale specimen described in this study represents a surface sample that has already suffered alteration by weathering or fluid overprinting.

Despite these limitations in knowledge, there exist a couple of arguments that strongly favor the non-metamorphic Kupferschiefer-type black shales as major source of Se and the accompanying metals. The phyllites have undergone a low-metamorphic overprint, during which present metals may have already been mobilized and re-deposited. The andesitic-dacitic lavas and tuffs have likely contributed to the origin of the Porco sulfide mineralization, and metals, such as Ag and Zn, enriched at Porco are very poor or missing at El Dragón. On the other hand, the black shales: (1) contain various $\mathrm{Cu}-\mathrm{Fe}$ sulfides displaying evidence of alteration (cf. Figure 22f); (2) are rich in framboidal pyrite (cf. Figure 22e) with elevated (detectable) concentrations of $\mathrm{Cu}, \mathrm{Ni}$ and $\mathrm{Co}$, elements particularly enriched at El Dragon; (3) are simultaneously rich in organic matter, substances that are particularly capable of absorbing Se and other metals on their surface; and (4) on a global scale, such black shales are known as carriers of a large suite of metals, including those accompanying Se at El Dragón [27,28]. Pyrite, especially framboidal pyrite, in lithologies rich in organic matter has been confirmed to possibly substitute $\mathrm{Se}, \mathrm{Pb}, \mathrm{Hg}$ and $\mathrm{Au}$ at concentrations of several 10 to several 100 ppm [29-31], i.e., at levels below their microprobe detection limits achieved in this study. The $\mathrm{Cu}$ - and Fe-sulfides in our black shale may as well have isomorphically substituted $\mathrm{Ag}, \mathrm{Cd}$ and $\mathrm{Bi}$ to an extent that permitted formation of the respective Se-species formed at El Dragón. Selenium itself may not only be present as minor component in sulfides where it replaces $\mathrm{S}$, but is also prone being bound within organic matter [32]. It exists in four oxidation states, all of which are highly redox-sensitive and have varying degrees of reactivity and solubility [33].

To conclude, it is fair to assume that the Kupferschiefer-type black shales adjacent to the Se-vein acted as major host rock for the elements that are immobilized in the various crystallized selenides at El Dragón. Processes involving highly oxidized fluids have likely oxidized and dissolved the S-minerals and mobilized absorbed and organic-bound selenium. During interaction with these fluids, reduced selenide $\left(\mathrm{Se}^{2-}\right)$ became oxidized to selenate $\left(\mathrm{Se}^{6+}\right)$ capable to migrate and deposit outside of the host. The $S$ freed up in response to destabilization of the sulfides got oxidized as well, but became probably fixed already close to the site of removal, in $\mathrm{cm}$ - to dm-sized baryte veins cross-cutting the black shales. Selenate was again reduced to selenide or even native selenium when the migrating fluids lost their oxidation potential through interaction with reductants inside the siltstone or at the interface between siltstone and black shales, triggering the deposition of the plethora of primary Se-species accumulated at this site.

\subsection{Origin of Se Mineralization}

Formation of the Se vein at El Dragón was multiphase, involving several episodes of deformation, fluid infiltration, mineral deposition and re-deposition, as well as alteration. Considering the current knowledge on the geology and structural and geochronological evolution of the greater Porco mining area in late Tertiary-Quaternary time [15], we propose the following model for the genesis of the El Dragon Se-vein (cf. Figures 1 and 4).

1. Eruption of the dacitic Porco tuff forming the Apo Porco stock at $\sim 12 \mathrm{Ma}$. This volcanic event did not give rise to ore mineralization, but caused $\mathrm{E}-\mathrm{W}$ trending compressional tectonism und subsequent fracturing perpendicular to the sedimentary bedding. Thus, it aided in the generation of the migration pathways (surface faults), along which subsequently the mineralizing fluids travelled. 
2. Formation of the andesitic-dacitic Huayna Porco stocks at $\sim 8.6 \mathrm{Ma}$. This event is associated with the formation of the Porco $\mathrm{Ag}-\mathrm{Pb}-\mathrm{Zn}$-sulfide vein deposit inside the Porco caldera, attesting to the strong hydrothermal activity connected with this volcanic event. It probably also triggered another episode of generation of new and re-opening of existing fractures perpendicular to the sedimentary bedding ( $d 1$ and $d 2$ ). Along some of these faults, $\mathrm{Cu}-\mathrm{Ag}-\mathrm{Ni}-\mathrm{Co}-\mathrm{Hg}-\mathrm{Pb}-\mathrm{Bi}-\mathrm{Se}$ mineralized oxidizing fluids multiply infiltrated the siltstone and deposited its metalliferous load wherever meeting a reducing environment. Reducing conditions were achieved at the interface siltstone/black shale, around pyrite grains and black-shale xenoliths inside the siltstone, or may have been microbially mediated [34,35]. The mineralizing low-T fluids $\left(<110{ }^{\circ} \mathrm{C}\right.$ considering the T-dependence of umangite stability, [36]) likely represent a mixture of convective low-T hydrothermal solutions and descending heated-up meteoric waters. Multiple fluid infiltration and mineral precipitation processes gave rise to the mineral growth generations g1-g5.

3. Volcanic-hydrothermal activities continued over a time span of roughly $3 \mathrm{Ma}$, encompassing multiple eruptions of the andesitic to dacitic Los Frailes ash-flow tuffs. Early tuff eruptions caused strong fracturing of the Se-vein (rubble breccia, d3) associated with the local invasion of fluids that triggered the alteration of earlier formed g1-g5 $\mathrm{Cu}-\mathrm{Hg}-\mathrm{Pb}$-Bi-bearing selenides and re-deposition of the thereby mobilized elements as selenides of growth generation g6 (Figure 23). Formation of these selenides cementing the earlier grown selenide assemblages is confined to fracture fillings inside the Se-vein. Brittle deformation ( $d 3$ ) significantly opened space for the circulating fluid that partly corroded or dissolved the fragmented early selenide generations, thus enriching it in elements incompatible with their structure, mainly $\mathrm{Hg}, \mathrm{Pb}$ and $\mathrm{Bi}$. Together with the omnipresent $\mathrm{Cu}$ and $\mathrm{Se}$, these elements in solution were re-precipitated as generation-(g6) selenides.

4. At some later stage, other andesitic to dacitic lavas erupted, probably forming a thin, only some tens-of-meters thick cover on the Se-vein and its neighboring rocks, which now is eroded. These volcanic rocks sealed the structure and likely expelled $\mathrm{Cu}$-Fe-S-rich hydrothermal solutions (note the occurrence of thin chalcopyrite-bearing veinlets between the volcanics and the black shale, see Figure 22a). Brittle deformation of the existing mineralization $(d 4)$ resulted in a finely branched system of tension cracks that where subsequently cemented by $\mathrm{Cu}-\mathrm{Fe}-\mathrm{Ni}$ sulfides of growth generation g7. These S-minerals partially interacted with pre-existing selenides, in particular the main krut'aite-penroseite ore, which, for example, provided the Ni required to crystallize vaesite. Crystallization of sulfides and liberation of selenium from attacked selenides shifted the fluid composition towards a Se/S ratio sufficiently high to again precipitate selenides (partially S-bearing) at the end of this episode.

5. Finally, at some unknown time between $6 \mathrm{Ma}$ and today, another brittle deformation event (d5) caused re-opening of the Se-vein structure, associated with the infiltration of highly oxidized meteoric waters. Wherever these fluids got in contact with the pre-existing selenides along fractures and inside of voids, they severely altered and cannibalized the earlier mineral assemblages, giving rise to a plethora of secondary minerals (g8) shown in Figure 19.

Considering the thermodynamic properties of binary selenides at $\mathrm{T}=100^{\circ} \mathrm{C}$ and elevated oxygen fugacities above that were defined by the magnetite-hematite buffer [37], the absolute and relative selenium fugacities of the various mineralizing fluids could be constrained that prevailed during the entire evolution of the El Dragón mineralization. The earliest precipitated (g1)-selenides were intermediate members of the krut'aite-penroseite solid-solution series, defining, together with the absence of berzelianite, the Se-fugacity in the mineralizing fluid to a $\log f_{\mathrm{Se} 2}$ of roughly -14.5 to -15 (stability field of umangite and klockmannite). The lack of sulfides implies that $\log f_{\mathrm{S} 2}$ was maximal -22 , i.e., the Se/S fugacity was greater than unity already at the earliest stage of mineralization. Subsequently precipitated solid solutions got progressively enriched in the krut'aite component, implying still higher Se-fugacities that were, however, less than that defined by the klockmannite-pure krut'aite univariant reaction $\left(\log f_{\mathrm{Se} 2}\right.$ about -11.2$)$. The fluid compositions remained (given the omnipresence of umangite and klockmannite), but slightly fluctuated (note the numerous systematic 
changes in the composition of the krut'aite-penroseite solid solutions) in this Se-fugacity interval until the growth generation (g6) was precipitated. The fluid from which the early sulfides of growth generation (g7) crystallized, was distinct in that it possessed higher S-fugacities than any other mineralizing fluids before, amounting to $\log f_{\mathrm{S} 2}$ between -22 and -17 . However, precipitation of sulfides and liberation of Se from pre-existing selenides enriched the fluid in Se up to a magnitude that finally permitted the formation of end-member krut'aite and native selenium, corresponding to a minimum $\log f_{\mathrm{Se} 2}$ of -11.2 (lower stability limit of native Se). The solution that finally caused the widespread alteration of the selenide-sulfide assemblages (growth generation g8) was comparatively still more oxidized (note the occurrence of anglesite), but contemporaneously equally rich in Se, as evidenced by the formation of native Se.

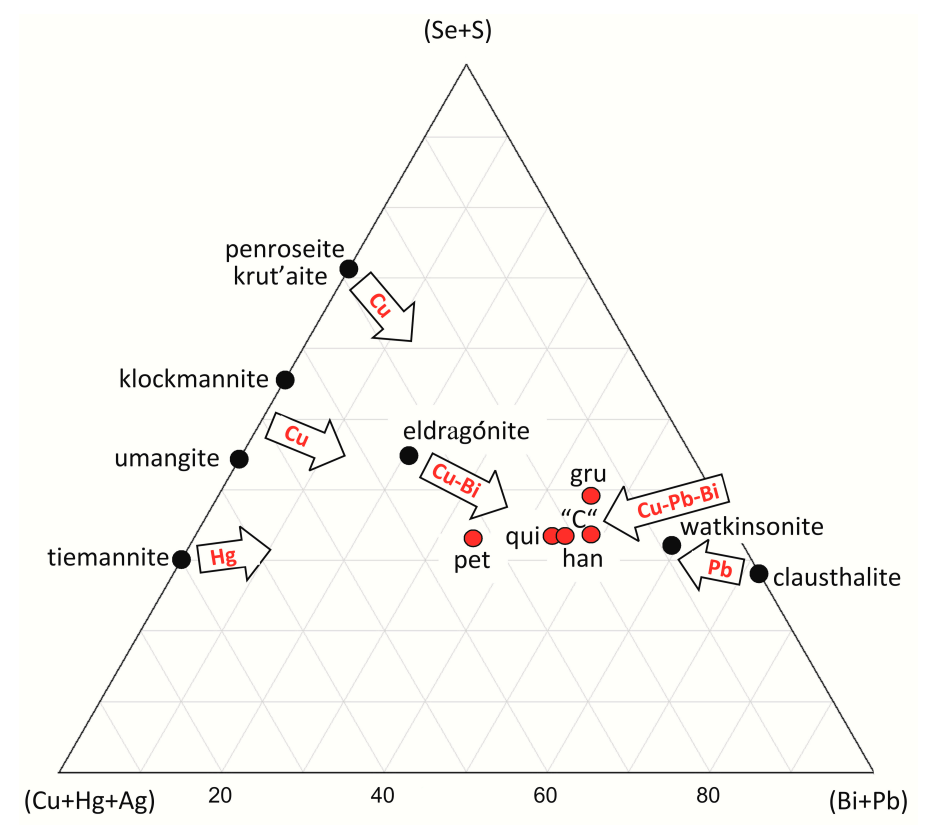

Figure 23. $(\mathrm{Cu}+\mathrm{Hg}+\mathrm{Ag})-(\mathrm{Bi}+\mathrm{Pb})-(\mathrm{Se}+\mathrm{S})($ wt $\%)$ ternary diagram showing the mean compositions of several g1-g5 selenides from El Dragón. Black dots indicate species that became partially to completely dissolved in response to fluid inflow following deformation stage $d 3$. Elements in red inside the arrows mark the most important cations mobilized from these species during this event. Together with Se, these elements governed the formation of $\mathrm{Cu}-\mathrm{Hg}-\mathrm{Pb}-\mathrm{Bi}$ selenides of growth generation $\mathrm{g} 6$ marked with red dots (gru = grundmannite, han = hansblockite, qui = quijarroite, " $\mathrm{C}$ " = unnamed phase " $\mathrm{C}$ ", pet $=$ petrovicite).

Acknowledgments: We are indebted to Luca Bindi and Chris J. Stanley for their contribution to the description of the new minerals grundmannite, hansblockite, and quijarroite. Günter Grundmann would like to thank Günter Hübner for critical discussion of the petrographic observations, and Gerhard Lehrberger for additional samples. Dieter Rhede and Oona Appelt assisted with the electron-microprobe analyses. Comments and suggestions of three anonymous reviewers are acknowledged.

Author Contributions: Günter Grundmann manufactured the thin- and polished sections, performed the microstructural analysis, and determined the genetic sequence of mineral deposition and alteration. Hans-Jürgen Förster conducted the electron-microprobe analyses. Hans-Jürgen Förster and Günter Grundmann wrote the paper.

Conflicts of Interest: The authors declare no conflict of interest.

\section{References}

1. Sejkora, J.; Makovicky, E.; Topa, D.; Putz, H.; Zagler, G.; Plašil, J. Litochlebite, $\mathrm{Ag}_{2} \mathrm{PbBi}_{4} \mathrm{Se}_{8}$, a new selenide mineral species from Zálesí, Czech Republic, description and crystal structure. Can. Mineral. 2011, 49, 639-650. [CrossRef] 
2. Paar, W.H.; Cooper, M.A.; Mó́elo, Y.; Stanley, C.J.; Putz, H.; Topa, D.; Roberts, A.C.; Stirling, J.; Raith, J.G.; Rowe, R. Eldragónite, $\mathrm{Cu}_{6} \mathrm{BiSe}_{4}(\mathrm{Se})_{2}$, a new mineral species from the El Dragón mine, Potosí, Bolivia, and its crystal structure. Can. Mineral. 2012, 50, 281-294. [CrossRef]

3. Mills, S.J.; Kampf, A.R.; Christy, A.G.; Housley, R.M.; Thorne, B.; Chen, Y.-S.; Steele, I.M. Favreauite, a new selenite mineral from the El Dragón mine, Bolivia. Eur. J. Mineral. 2014, 26, 771-781. [CrossRef]

4. Bindi, L.; Förster, H.-J.; Grundmann, G.; Keutsch, F.N.; Stanley, C.J. Petř́čckite, CuSe 2 , a new member of the marcasite group from the Předbořice deposit, Central Bohemia Region, Czech Republic. Minerals 2016, 6, 33. [CrossRef]

5. Förster, H.-J.; Bindi, L.; Stanley, C.J. Grundmannite, $\mathrm{CuBiSe}_{2}$, the Se-analogue of emplectite: A new mineral from the El Dragón mine, Potosí, Bolivia. Eur. J. Mineral. 2016, 28, 467-477. [CrossRef]

6. Förster, H.-J.; Bindi, L.; Stanley, C.J.; Grundmann, G. Hansblockite, $(\mathrm{Cu}, \mathrm{Hg})(\mathrm{Bi}, \mathrm{Pb}) \mathrm{Se}_{2}$, the monoclinic polymorph of grundmannite, a new mineral from the Se mineralization at El Dragón (Bolivia). Mineral. Mag. 2016. [CrossRef]

7. Förster, H.-J.; Bindi, L.; Stanley, C.J.; Grundmann, G. Quijarroite, $\mathrm{Cu}_{6} \mathrm{HgPb}_{2} \mathrm{Bi}_{4} \mathrm{Se}_{12}$, a new selenide from the El Dragón mine, Bolivia. Minerals 2016, 6, 123. [CrossRef]

8. Kampf, A.R.; Mills, S.J.; Nash, B.P.; Thorne, B.; Favreau, G. Alfredopetrovite: A new selenite mineral from the El Dragón mine. Eur. J. Mineral. 2016. [CrossRef]

9. Š́kácha, P.; Sejkora, J.; Plášil, J. Příbramite, IMA 2015-127, CNMNC Newsletter No. 31, June 2016, page 693. Mineral. Mag. 2016, 80, 691-697.

10. Škácha, P.; Sejkora, J.; Plášil, J. Bytízite, IMA 2016-044, CNMNC Newsletter No. 33, October 2016, page 1138. Mineral. Mag. 2016, 80, 1135-1144.

11. Cabral, A.R.; Ließmann, W.; Jian, W.; Lehmann, B. Bismuth selenides from St. Andreasberg, Germany: An oxidized five-element style of mineralization and its relation to post-Variscan vein-type deposits of central Europe. Int. J. Earth Sci. 2016. [CrossRef]

12. Block, H.; Ahlfeld, F. Die Selenerzlagerstatte Pacajake, Bolivia. Z. Prakt. Geol. 1937, 45, 9-14.

13. Redwood, S.D. Famous mineral localities: The Pacajake selenium mine, Potosí, Bolivia. Mineral. Rec. 2003, 34, 339-357.

14. Grundmann, G.; Lehrberger, G.; Schnorrer-Köhler, G. The El Dragón mine, Potosí, Bolivia. Mineral. Rec. 1990, 21, 133-146.

15. Cunningham, C.A.; Aparicio, H.N.; Murillo, F.S.; Jiménez, N.C.; Lizeca, J.-L.B.; McKee, E.H.; Ericksen, G.E.; Tavera, F.V. The Relationship between the Porco, Bolivia, Ag-Zn-Pb-Sn Deposit, and the Porco Caldera; US Geological Survey Open-File Report 94-238; Society of Economic Geologists: Littleton, CO, USA, 1993.

16. Frutos, J. The Andes Cordillera: A synthesis of the geological evolution. In Stratabound Ore Deposits of the Andes; Fontbote, L., Amstutz, G., Cardozo, M., Cedillo, E., Frutos, J., Eds.; Springer: Berlin, Germany, 1990; pp. 3-36.

17. Grundmann, G.; Lehrberger, G.; Schnorrer-Köhler, G. The “El Dragon Mine”, Porco, Potosí, Bolivia-Selenium Minerals. Mineral 2007, 1, 16-25.

18. Johan, Z.; Picot, P.; Kvačeck, M. La krut'aite, $\mathrm{CuSe}_{2}$, un nouveau minéral du groupe da la pyrite. Bull. Soc. Fr. Minéral. Cristallogr. 1972, 95, 475-481. (In French)

19. Anthony, J.W.; Bideaux, R.A.; Bladh, K.W.; Nichols, M.C. Handbock of Mineralogy, Vol. I, Trogtalite; Mineralogical Society of America: Chantilly, VA, USA, 1990; Volume 1, p. 537.

20. Paar, W.H.; Sureda, R.J.; de Brodtkorb, M.K. Mineralogía de los yaciminientos de selenio en La Rioja, Argentina. Krutaita, tyrrellita y trogtalita de Los Llantenes. Rev. Asoc. Geol. Argent. 1996, 51, 304-312. (In Spanish)

21. Paar, W.H.; Topa, D.; Roberts, A.C.; Criddle, A.J.; Amann, G.; Sureda, R.J. The new mineral species Brodtkorbite, $\mathrm{Cu}_{2} \mathrm{HgSe}_{2}$, and the associated selenide assemblage from Tuminico, Sierra de Cacho, La Rioja, Argentina. Can. Mineral. 2002, 40, 225-237. [CrossRef]

22. Keutsch, F.N.; Förster, H.-J.; Stanley, C.J.; Rhede, D. The discreditation of hastite, the orthorhombic dimorph of $\mathrm{CoSe}_{2}$, and observations on trogtalite, cubic $\mathrm{CoSe}_{2}$, from the type locality. Can. Mineral. 2009, 47, 969-976. [CrossRef]

23. Criddle, A.J.; Stanley, C.J. The Quantitative Data File for Ore Minerals, 2nd ed.; British Museum (Natural History): London, UK, 1986; pp. 274-275. 
24. Stanley, C.J.; Criddle, A.J.; Lloyd, D. Precious and base metal selenide mineralization at Hope's Nose, Torquay, Devon. Mineral. Mag. 1990, 54, 485-493. [CrossRef]

25. Bindi, L.; Cipriani, C.; Pratesi, G.; Trosti-Ferroni, R. The role of isomorphous substitutions in natural selenides belonging to the pyrite group. J. Alloys Compd. 2008, 459, 553-556. [CrossRef]

26. Large, D.J.; Sawłowicz, Z.; Spratt, J. A cobaltite-framboidal pyrite association from the Kupferschiefer: Possible implications for trace element behavior during the earliest stages of diagenesis. Mineral. Mag. 1999, 63, 353-361. [CrossRef]

27. Zur Geschichte des Mansfelder Kupferschiefer-Bergbaus; Jankowski, G. (Ed.) GDMB Informationsgesellschaft: Clausthal-Zellerfeld, Germany, 1995.

28. Speczik, S. The Kupferschiefer mineralization of Central Europe: New aspects and major areas for future research. Ore Geol. Rev. 1995, 9, 411-426. [CrossRef]

29. Diehl, S.F.; Goldhaber, M.B.; Koenig, A.E.; Lowers, H.A.; Ruppert, L.F. Distribution of arsenic, selenium, and other trace elements in high pyrite Appalachian coals; evidence for multiple episodes of pyrite formation. Int. J. Coal Geol. 2012, 94, 238-249. [CrossRef]

30. Kiss, G.B.; Zaccarini, F. Development of framboidal pyrite in the upper Permian marly limestone of the NE-Hungarian Darnó Hill. Geol. Croat. 2012, 66, 233-244. [CrossRef]

31. Parnell, J.; Brolly, C.; Spinks, S.; Bowden, S. Selenium enrichment in Carboniferous shales, Britain and Ireland: Problem or opportunity for shale gas extraction. Appl. Geochem. 2016, 66, 82-87. [CrossRef]

32. Yudovich, Y.E.; Ketris, M.P. Selenium in coal: A review. Int. J. Coal Geol. 2006, 67, 112-126. [CrossRef]

33. Ryser, A.L.; Strawn, D.G.; Marcus, M.A.; Johnson-Maynard, J.L.; Gunter, M.E.; Möller, G. Micro-spectroscopic investigation of selenium-bearing minerals from the Western US phosphate resource area. Geochem. Trans. 2005, 6, 1-11. [CrossRef]

34. Matlakowska, R.; Skłodowska, A.; Nejbert, K. Bioweathering of Kupferschiefer black shale (Fore-Sudetic Monocline, SW Poland) by indigenous bacteria: Implications for dissolution and precipitation of minerals in deep underground mine. FEMS Microbiol. Ecol. 2012, 81, 99-110. [CrossRef] [PubMed]

35. Spinks, S.C.; Parnell, J.; Still, J.W. Redox-controlled selenide mineralization in the Upper Old Red Sandstone. Scott. J. Geol. 2014, 50, 173-182. [CrossRef]

36. Chakrabarti, D.J.; Laughlin, D.C. The Cu-Se (copper-selenium) system. Bull. Alloy Phase Diagr. 1981, 2, 305-315. [CrossRef]

37. Simon, G.; Kesler, S.E.; Essene, E.J. Phase relations among selenides, sulphides, tellurides, and oxides: II. Applications to selenide-bearing ore deposits. Econ. Geol. 1997, 92, 468-484. [CrossRef]

(C) 2017 by the authors. Licensee MDPI, Basel, Switzerland. This article is an open access article distributed under the terms and conditions of the Creative Commons Attribution (CC BY) license (http:/ / creativecommons.org/licenses/by/4.0/). 